NATIONAL LABORATORY

\title{
Summary and Analysis of Responses to Surveys on Experience with GHP Installations in Federal Facilities and Minimum Qualifications of GHP-related Professionals
}

\author{
(Final)
}

September 2012

Prepared by

Xiaobing Liu

Diana Hun

John Shonder

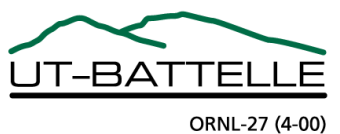




\section{DOCUMENT AVAILABILITY}

Reports produced after January 1, 1996, are generally available free via the U.S. Department of Energy (DOE) Information Bridge.

Web site http://www.osti.gov/bridge

Reports produced before January 1, 1996, may be purchased by members of the public from the following source.

National Technical Information Service

5285 Port Royal Road

Springfield, VA 22161

Telephone 703-605-6000 (1-800-553-6847)

TDD 703-487-4639

Fax 703-605-6900

E-mail info@ntis.gov

Web site http://www.ntis.gov/support/ordernowabout.htm

Reports are available to DOE employees, DOE contractors, Energy Technology Data Exchange (ETDE) representatives, and International Nuclear Information System (INIS) representatives from the following source.

Office of Scientific and Technical Information

P.O. Box 62

Oak Ridge, TN 37831

Telephone 865-576-8401

Fax 865-576-5728

E-mail reports@osti.gov

Web site http://www.osti.gov/contact.html

This report was prepared as an account of work sponsored by an agency of the United States Government. Neither the United States Government nor any agency thereof, nor any of their employees, makes any warranty, express or implied, or assumes any legal liability or responsibility for the accuracy, completeness, or usefulness of any information, apparatus, product, or process disclosed, or represents that its use would not infringe privately owned rights. Reference herein to any specific commercial product, process, or service by trade name, trademark, manufacturer, or otherwise, does not necessarily constitute or imply its endorsement, recommendation, or favoring by the United States Government or any agency thereof. The views and opinions of authors expressed herein do not necessarily state or reflect those of the United States Government or any agency thereof. 
Energy and Transportation Science Division

\title{
Summary and Analysis of Responses to Surveys on Experience with GHP Installations in Federal Facilities and Minimum Qualifications of GHP- Related Professionals
}

\author{
Xiaobing Liu \\ Diana Hun \\ John Shonder
}

Date Published: September 2012

Prepared by

OAK RIDGE NATIONAL LABORATORY

Oak Ridge, Tennessee 37831-6283

managed by

UT-BATTELLE, LLC

for the

U.S. DEPARTMENT OF ENERGY

under contract DE-AC05-00OR22725 



\section{CONTENTS}

\begin{tabular}{|c|c|c|}
\hline \multicolumn{3}{|c|}{ 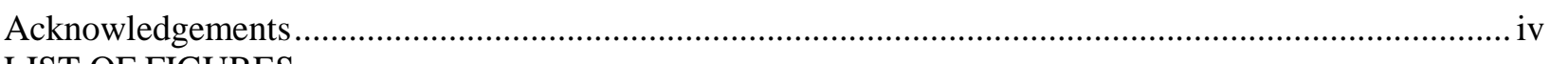 } \\
\hline \multirow{2}{*}{\multicolumn{3}{|c|}{$\begin{array}{l}\text { LIST OF FIGURES } \\
\text { LIST OF TABLES }\end{array}$}} \\
\hline & & \\
\hline \multirow{2}{*}{\multicolumn{3}{|c|}{ INTRODUCTION }} \\
\hline \multirow[t]{11}{*}{2.} & & \\
\hline & RESL & LTS FROM THE SURVEY ON GHP SYSTEMS INSTALLED IN FEDERAL \\
\hline & FACI & LITIES . \\
\hline & 2.1 .1 & Profile of \\
\hline & 2.1 .2 & Status of GHP Systems Installed in Federal Facilities.... \\
\hline & 2.1 .3 & Consumer Satisfaction with Installed GHP Systems ............ \\
\hline & 2.1 .4 & Common Causes of Malfunctioning GHP Systems ..... \\
\hline & 2.1 .5 & Best Practices to Deliver High-Quality GHP Systems .... \\
\hline & 2.1 .6 & Disciplines Involved in GHP Projects \\
\hline & 2.1 .7 & Qualifications of Disciplines.... \\
\hline & 2.1 .8 & Key Barriers Preventing Wider Adoption of GHP Syste \\
\hline \multirow[t]{5}{*}{2.2} & RESL & LTS FROM THE SURVEY REGARDING MINIMUM QUALIFICATIONS. \\
\hline & 2.2.1 & Profile of Survey Respondents....................................... \\
\hline & 2.2 .2 & Opinions Regarding the Pre-defined Disciplines in the GHP Industry ................... \\
\hline & 2.2 .3 & Opinions on Minimum Qualification Requirements for GHP Disciplines ................. 21 \\
\hline & 2.2 .4 & Additional Comments from Survey Respondents................. \\
\hline \multicolumn{3}{|c|}{ 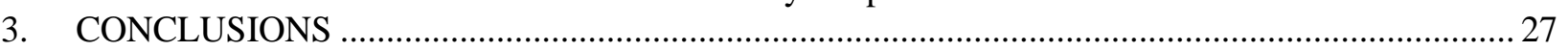 } \\
\hline \multicolumn{3}{|c|}{ REFERENCES } \\
\hline \multicolumn{3}{|c|}{ APPENDIX A: ADDITIONAL INFORMATION PROVIDED BY RESPONDENTS TO THE } \\
\hline \multicolumn{3}{|c|}{ SURVEY OF FEDERAL EXPERIENCE ON GHP SYSTEMS ….......................................... } \\
\hline \multirow{2}{*}{\multicolumn{3}{|c|}{$\begin{array}{l}\text { APPENDIX B: COMMENTS FROM RESPONDENTS WITH REGARD TO THE SURVEY OF } \\
\text { MINIMUM QUALIFICATIONS OF GHP DISCIPLINES }\end{array}$}} \\
\hline & & \\
\hline \multicolumn{3}{|c|}{ APPENDIX C: PRE-DEFINED GHP DISCIPLINES ................... } \\
\hline
\end{tabular}




\section{ACKNOWLEDGEMENTS}

The Geothermal Heat Pump Consortium (GHPC, now known as the Geothermal Exchange Organization or GEO) was competitively selected under the U.S. Department of Energy's, American Recovery and Reinvestment Act, Ground Source Heat Pump solicitation DE-FOA-0000116, to create a national certification standard for all primary personnel involved in the installation of geothermal heat pump (GHP) systems. In addition to GHPC, team members included the International Ground Source Heat Pump Association, the National Ground Water Association, and Oak Ridge National Laboratory (ORNL). This report documents an ORNL task under the program. Special thanks to John Kelly, the Executive Director of GHPC, for his guidance and support. The authors also wish to acknowledge Phil Henry, the president of Geoexchange Solutions, Inc. for his invaluable contributions in implementing this survey; and Patrick Hughes, Piljae Im, and Bruce Tonn at Oak Ridge National Laboratory for their input and review. 


\section{LIST OF FIGURES}

Figure

Fig. 1. The geographical coverage of all the GHP systems surveyed.................................................... 3

Fig. 2. GHP disciplines represented by the survey respondents. ................................................. 4

Fig. 3. Years since the first GHP system was commissioned in the surveyed facilities............................ 5

Fig. 4. Percentage of GHP applications in the surveyed federal facilities.............................................. 5

Fig. 5. Survey results regarding whether the surveyed federal facilities have any plans to expand

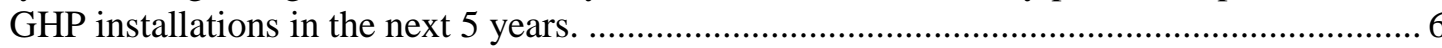

Fig. 6. Survey results regarding whether the surveyed federal facilities have set any goal to use GHP systems in a certain percentage of buildings at the facilities........................................ 6

Fig. 7. Types of heat pump equipment used in the surveyed GHP systems. ............................................ 7

Fig. 8. Survey results for space-conditioning systems used in GHP systems......................................... 8

Fig. 9. Survey results for how GHP systems are used for domestic water heating................................... 8

Fig. 10. Overall satisfaction level with regard to the GHP systems in the surveyed facilities. .................. 9

Fig. 11. Satisfaction level with regard to specific aspects of the surveyed GHP systems. ....................... 10

Fig. 12. Contribution of various causes to malfunctioning GHP systems. .............................................. 11

Fig. 13. Survey results on which phases of a GHP project need improvement. ...................................... 11

Fig. 14. Survey results on where improvements are needed in each phase of a GHP project. .................. 12

Fig. 15. Recommended best practices to deliver high-quality GHP systems. .......................................... 13

Fig. 16. Survey results on disciplines that helped the federal facilities implement the GHP systems........ 14

Fig. 17. Survey results on qualification requirements for GHP disciplines............................................ 15

Fig. 18. Survey results on barriers preventing wider adoption of GHP systems in federal facilities. ........ 16

Fig. 19. GHP disciplines represented by survey respondents. ............................................................... 17

Fig. 20. Number of survey respondents who commented on the pre-defined GHP disciplines. ................ 18

Fig. 21. Survey responses on minimum education requirements for the pre-defined GHP disciplines...... 22

Fig. 22. Survey respondents' opinions on the minimum requirements for years of experience for the

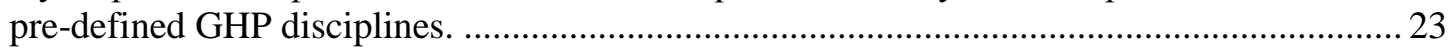

Fig. 23. Summary of all survey responses with regard to licensing or certification requirement for

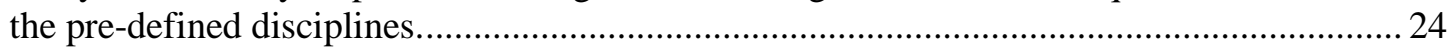





\section{LIST OF TABLES}

\section{Table}

Page

Table 1. Locations of the GHP systems being surveyed..................................................................... 3

Table 2. Types and share of ground heat exchangers used in the surveyed GHP systems ......................... 7

Table 3. Pre-defined GHP discipline classifications and comments by survey respondents ...................... 19

Table 4. Licensing or certification requirement with top three voting rates for each of the pre-

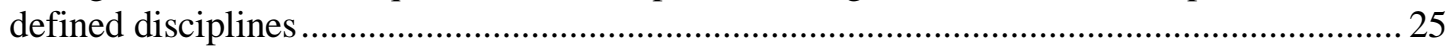





\section{INTRODUCTION}

To increase customer confidence in geothermal heat pump (GHP) technology, reduce the potential of improperly installed GHP systems, and ensure the quality and performance of GHP installations, the Geothermal Heat Pump Consortium (GHPC, now known as the Geothermal Exchange Organization or GEO) is leading an effort to develop the first national certification standard for all primary personnel involved in the implementation of GHP systems. This standard will be developed through a collaborative methodology that solicits information and input from consumers, industry stakeholders, and professional and trade organizations to identify the required qualifications of all the primary personnel and incorporate this information into the standard.

As a participant in this project, Oak Ridge National Laboratory (ORNL) developed and conducted two surveys to collect the following information to support the development of this standard.

1. Current status and customer perceptions with regard to existing GHP systems

2. Best practices in the design and installation of GHP systems

3. Common causes of malfunctioning GHP systems and areas needing improvement

4. Classifications of disciplines required for implementing GHP systems

5. Qualification requirements for the disciplines involved in GHP projects

Below are brief descriptions of the two surveys and their targeted audiences.

\section{- Survey on Federal Experience with GHP Systems}

This survey focuses on depicting the current status of GHP applications in the US federal government, which has a large installed base of GHP systems. Federal buildings compose the largest single potential market for GHP installations. In addition, this survey tries to identify the profile of the professionals who implemented these GHP systems. This survey is designed for federal employees at the agency or facility level, or private-sector employees who have worked on GHP projects in federal facilities.

\section{- GHP Industry Stakeholder Survey}

This survey is to identify the consensus regarding the minimum qualifications of professionals for implementing GHP systems. It is designed for all GHP industry stakeholders.

The surveys comprise various types of multi-option questions and text boxes for input. To reduce the number of questions and the time required to take the survey, some questions are dynamically linked, with downstream questions varying depending on the answers to earlier questions. The surveys were implemented by WebSynergetics with LimeSurvey software and were available for online participation.

The surveys were announced and delivered to potential participants through various channels, including newsletters published by GHPC, the International Ground Source Heat Pump Association (IGSHPA), and the National Ground Water Association (NGWA). We also sent survey invitations to federal agencies, including the US Army, Air Force, Navy, Coast Guard, Army Corps of Engineers, and the General Services Administration, which has implemented GHP systems in its facilities (buildings and installations). Some of these federal agencies further distributed the survey invitation through appropriate command chain to their facilities.

In Section 2, the responses to these surveys are summarized. Conclusions drawn from the surveys are given in Section 3. The comments and additional input provided by the survey respondents are grouped in several categories and presented in Appendixes A and B of this report, along with other related information. 


\section{SUMMARY OF SURVEY RESULTS}

Summaries of the responses to each of the two surveys are presented in the following subsections.

\subsection{RESULTS FROM THE SURVEY ON GHP SYSTEMS INSTALLED IN FEDERAL FACILITIES}

In this subsection, the profile of the survey respondents is reviewed and the summary of survey responses

to each of the following topics is presented:

- Status of GHP applications in federal facilities

- Consumer satisfaction with the installed GHP systems

- Common causes of malfunctioning GHP systems

- Best practices for delivering high-quality GHP systems

- Disciplines required for implementing GHP systems

- Qualifications of GHP disciplines

- Key barriers preventing wider adoption of GHP systems

\subsubsection{Profile of Survey Respondents}

Twenty-one completed responses were received from this survey. Fourteen of the respondents are federal employees, and the other seven are private-sector employees who have worked on GHP projects in federal facilities.

As an optional question in the survey, participants were asked to provide the names and locations of the federal agencies with which the participants have had GHP experience. Sixteen respondents provided the name of the federal agencies, which included the US Army, Coast Guard, Army Corps of Engineers, Air Force, and Department of Defense. The GHP systems being surveyed are located in 21 different cities across 16 states, as shown in Table 1 and on the national map in Fig. 1. Most respondents to this survey are from the Department of Defense, which is the largest energy consumer in federal sector.

The seven respondents who are private-sector employees indicated that they played a variety of roles in the GHP projects. As shown in Fig. 2, Site Evaluator appears as the most general discipline and is the one where six of seven respondents identified themselves. In addition, the respondents represent the following disciplines (from highest to lowest number of participants): Ground Heat Transfer Designer, Standing Column Well Designer, GHP System Design Engineer, Vertical Borehole Driller, Ground Thermal Conductivity/Diffusivity Tester/Analyst, Water Well Designer, Return (Recharge) Well Designer, GHP System Commissioning Agent, GHP System Trainer, Loop Installer/Grouter, Water Well Driller, Water Well Pump Installer, GHP System Operation and Maintenance Personnel. No respondent identified himself/herself as an Architect, Horizontal Directional Driller, Trench/Excavator, Pipe/Tubing Technician, Mechanical System Installer, or GHP System Regulator. 
Table 1. Locations of the GHP systems being surveyed

\begin{tabular}{ll}
\hline \multicolumn{1}{c}{ State } & \multicolumn{1}{c}{ City } \\
\hline Alabama & Mobile \\
Arizona & Fort Huachuca \\
California & Fort Irwin \\
Florida & Tyndall AFB \\
Iowa & Wayland \\
Kansas & Fort Riley \\
Maine & Bangor \\
Maryland & Aberdeen \\
Massachusetts & Devens \\
Massachusetts & Brockton \\
Massachusetts & Bedford \\
New Hampshire & Londonderry \\
New Hampshire & Concord \\
North Carolina & Fayetteville \\
North Dakota & Minot AFB \\
Oklahoma & McAlester \\
Oklahoma & Fort Sill \\
Pennsylvania & Carlisle Barracks \\
South Carolina & Columbia \\
South Carolina & Beaufort \\
Tennessee & Clarksville \\
\hline
\end{tabular}

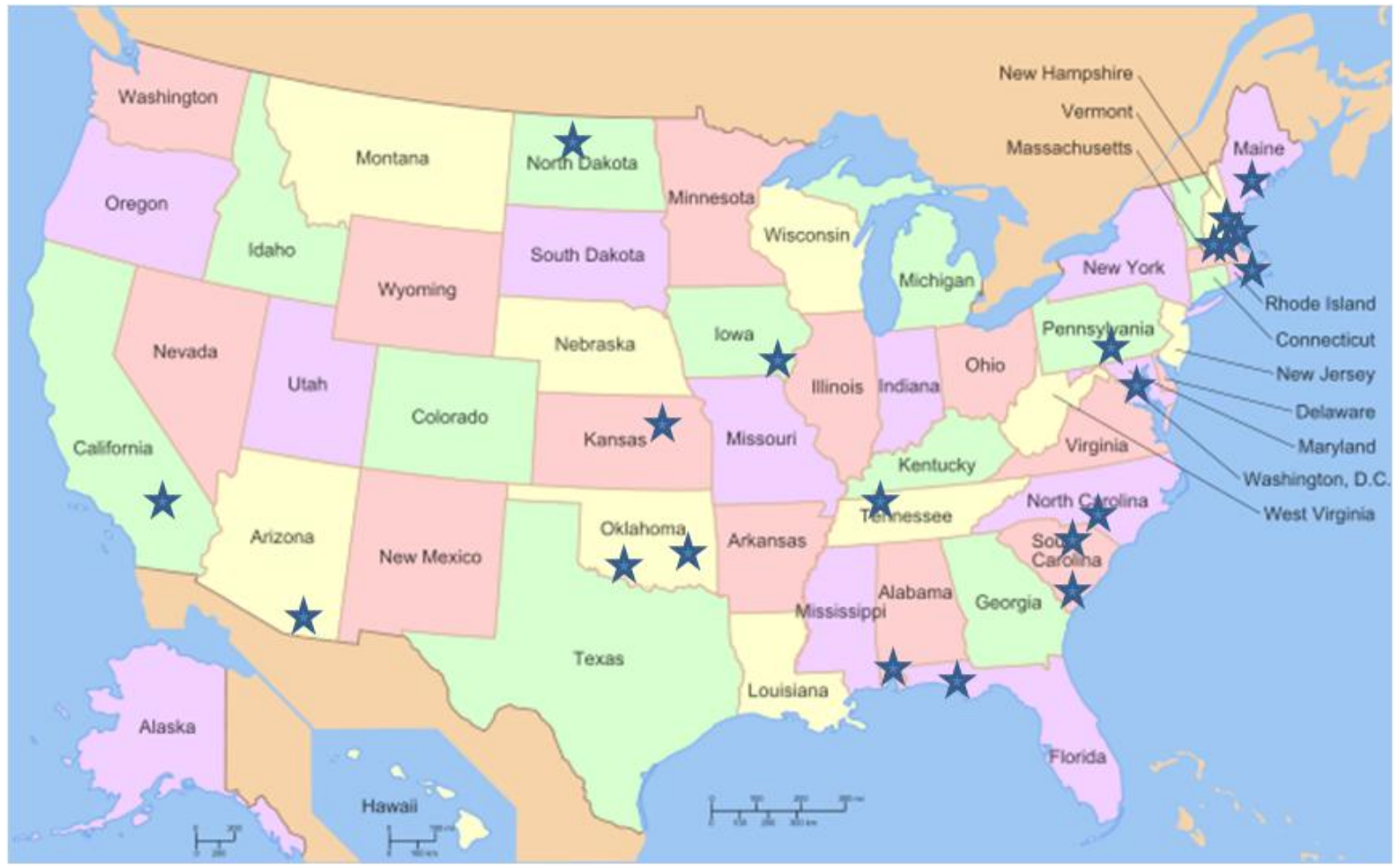

Fig. 1. The geographical coverage of all the GHP systems surveyed. 


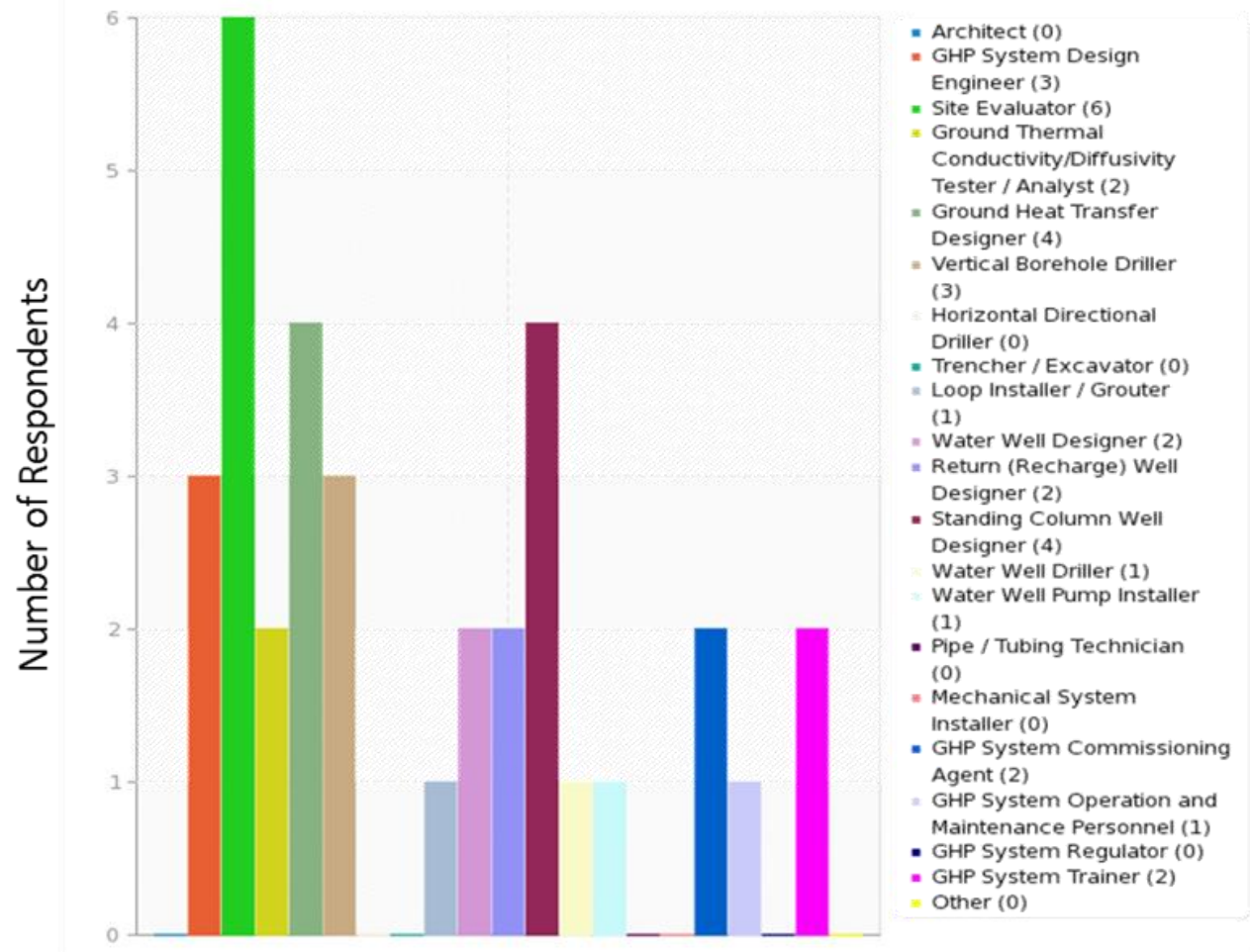

Fig. 2. GHP disciplines represented by the survey respondents.

\subsubsection{Status of GHP Systems Installed in Federal Facilities}

The respondents who are federal employees were asked about the history, current situation, and plans for adopting GHP systems in their facilities. In addition, all survey respondents were asked to provide some specific information about the GHP systems, including the types of ground heat exchangers (GHXs), heat pump equipment, and system configurations. The responses are summarized below.

\section{History}

The number of years since the first GHP system was commissioned at the various facilities varies widely, from less than 2 to more than 20 years (Fig. 3). The responses indicated that new GHP systems have been continuously implemented in federal facilities in the past 20 years, and more than $50 \%$ of the surveyed facilities commissioned their first GHP systems in the past 10 years.

\section{Current situation}

Figure 4 shows that $29 \%$ of the surveyed facilities are using GHP systems in less than $1 \%$ of their buildings; on the other hand, the same percentage of respondents indicated that GHP systems have been used in more than $10 \%$ of buildings in their facilities, and one respondent even indicated that all the buildings in a particular facility are using GHP systems. A respondent estimated that approximately 10 million $\mathrm{ft}^{2}$ of buildings across the US Army are using GHP systems: Fort Knox has approximately 6 million $\mathrm{ft}^{2}$ of buildings served by GHP systems, and approximately 100,000 $\mathrm{ft}^{2}$ of buildings in each of the other 40 Army installations are conditioned by GHP systems. By summing the inputs from all the respondents, it is found that totally 12 million $\mathrm{ft}^{2}$ buildings in the surveyed facilities are currently conditioned with GHP systems. 


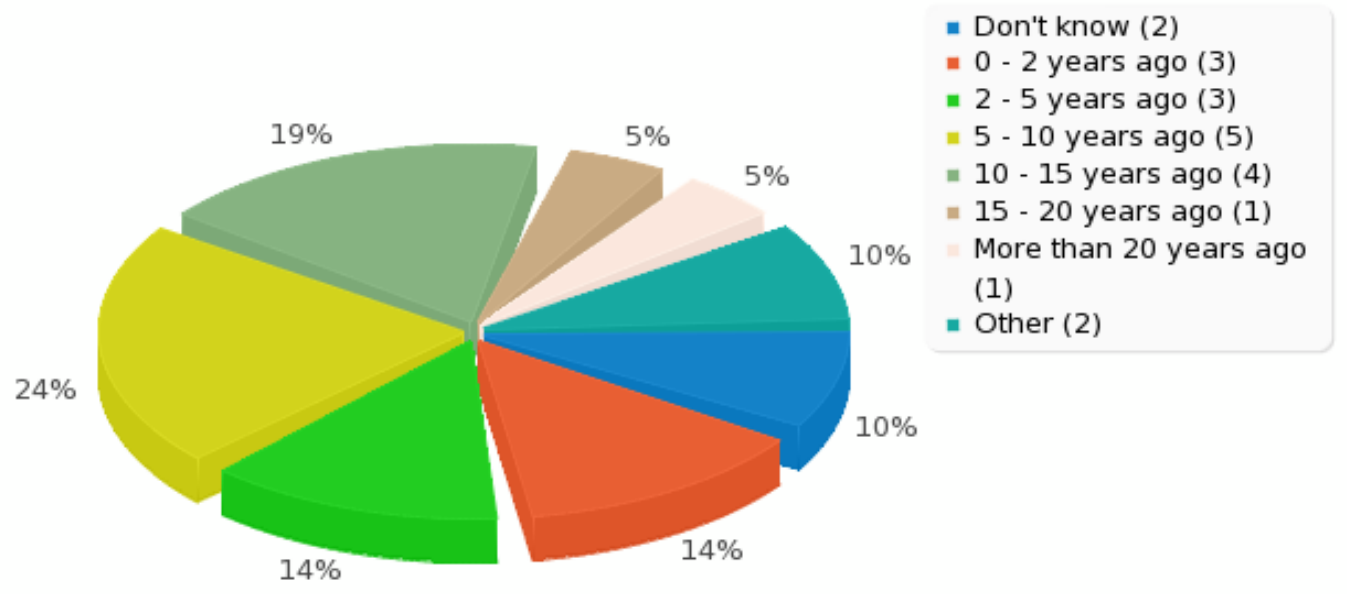

Fig. 3. Years since the first GHP system was commissioned in the surveyed facilities.

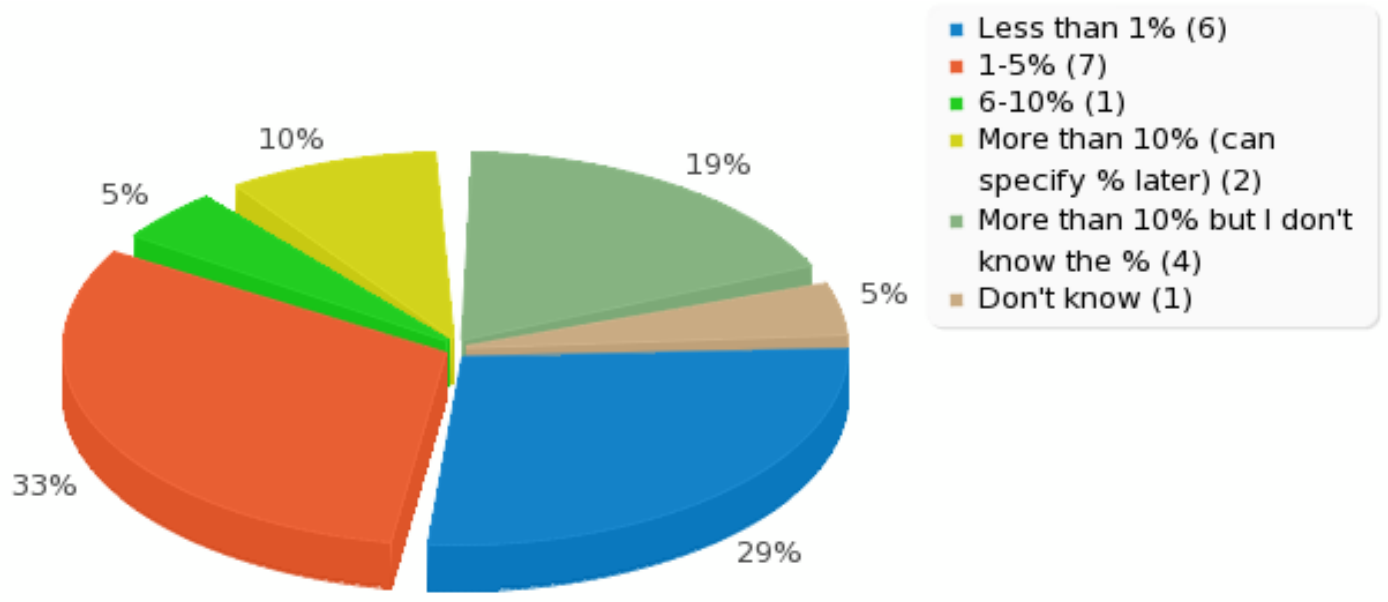

Fig. 4. Percentage of GHP applications in the surveyed federal facilities.

Among the 21 survey respondents, $9(43 \%), 13$ (62\%), and $5(24 \%)$ indicated GHP systems were used in residential, commercial, and other types of buildings, respectively. Since the respondents were allowed to select multiple building types, the resulting total number of building type selections is greater than the number of survey respondents. This finding is not surprising since a federal facility, such as a military base, may have various types of buildings, some of which are conditioned with GHP systems.

The survey responses also provided information regarding the estimated percentages of GHP systems in new construction and existing buildings. On average, $46.44 \%$ of the GHP systems are installed in new construction and $53.56 \%$ are installed in existing buildings.

\section{Plans for the future}

As shown in Figs. 5 and 6,12 of the 14 respondents (86\%) who are federal employees indicated that the facilities they work for will expand installations of GHP systems in the next 5 years. Furthermore, five respondents (36\% of the total) indicated that their facilities have set a specific goal to install GHP systems in at least a certain percentage of buildings of the facilities. 


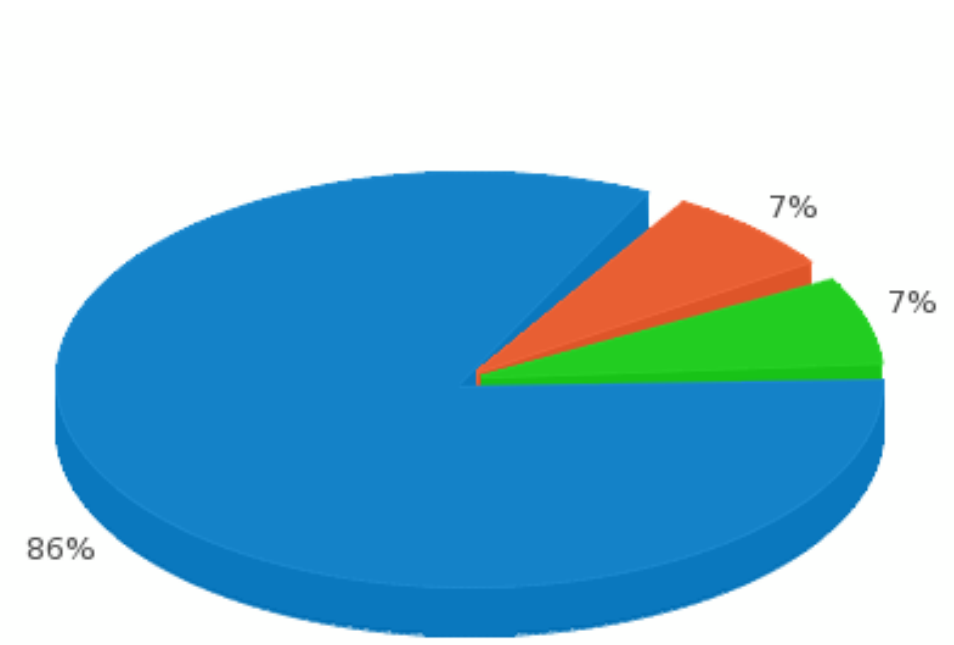

- Yes (12)

- No (1)

- No response or don't know

(1)

Fig. 5. Survey results regarding whether the surveyed federal facilities have any plans to expand GHP installations in the next 5 years.

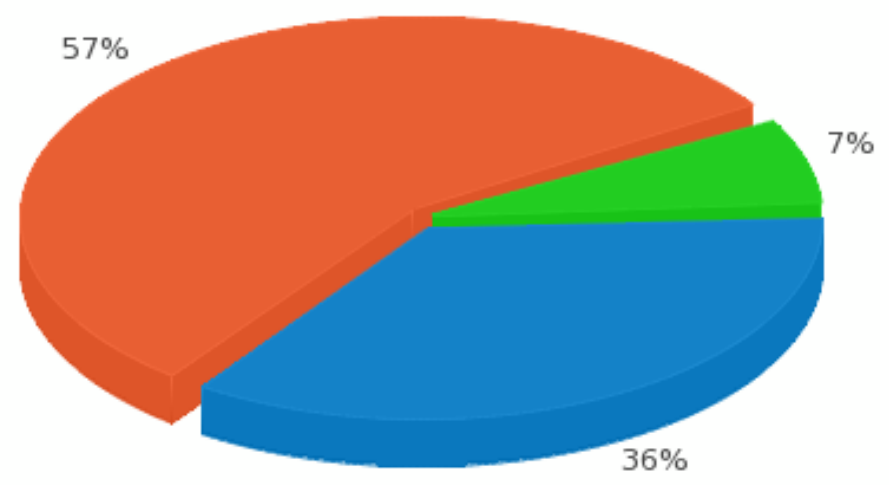

- Yes (5)

- No (8)

- No response or don't know

(1)

Fig. 6. Survey results regarding whether the surveyed federal facilities have set any goal to use GHP systems in a certain percentage of buildings at the facilities.

\section{Types of ground heat exchangers}

Table 2 lists the types of GHXs being used in the surveyed GHP systems and the average share of the total that each type accounts for, as estimated by the respondents. The vertical closed loop is the most widely used GHX (61\%), followed by standing column well (24\%), horizontal closed loop (7\%), groundwater open loop (5.9\%), and surface water closed loop $(0.4 \%)$. The respondents also mentioned a few other GHX types, including potable water heat exchanger, and a few combinations of various GHXs and cooling towers. These GHXs have been used in about $2 \%$ of the surveyed GHP systems. 
Table 2. Types and share of ground heat exchangers used in the surveyed GHP systems

\begin{tabular}{lr}
\hline \multicolumn{1}{c}{ GHX Types } & \multicolumn{1}{c}{ Share } \\
\hline Vertical closed loop & $61.0 \%$ \\
Horizontal closed loop & $7.0 \%$ \\
Standing column well & $24.0 \%$ \\
Groundwater open loop & $5.9 \%$ \\
Surface water open loop & $0.0 \%$ \\
Surface water closed loop & $0.4 \%$ \\
Other & $2.0 \%$ \\
\hline
\end{tabular}

\section{Heat pump equipment}

Figure 7 charts survey results regarding the types of heat pump equipment being used in GHP systems. Of the 21 respondents, $18(85.7 \%)$ indicated that small packaged heat pump units (equal to or less than 30 tons) were used; 7 of $21(33.3 \%)$ respondents indicated large central heat pump chillers (greater than 30 tons) were used. The sum of the percentages for small packaged and large central heat pump equipment exceeds $100 \%$, which indicates that both types of heat pump equipment have been used in some federal facilities.

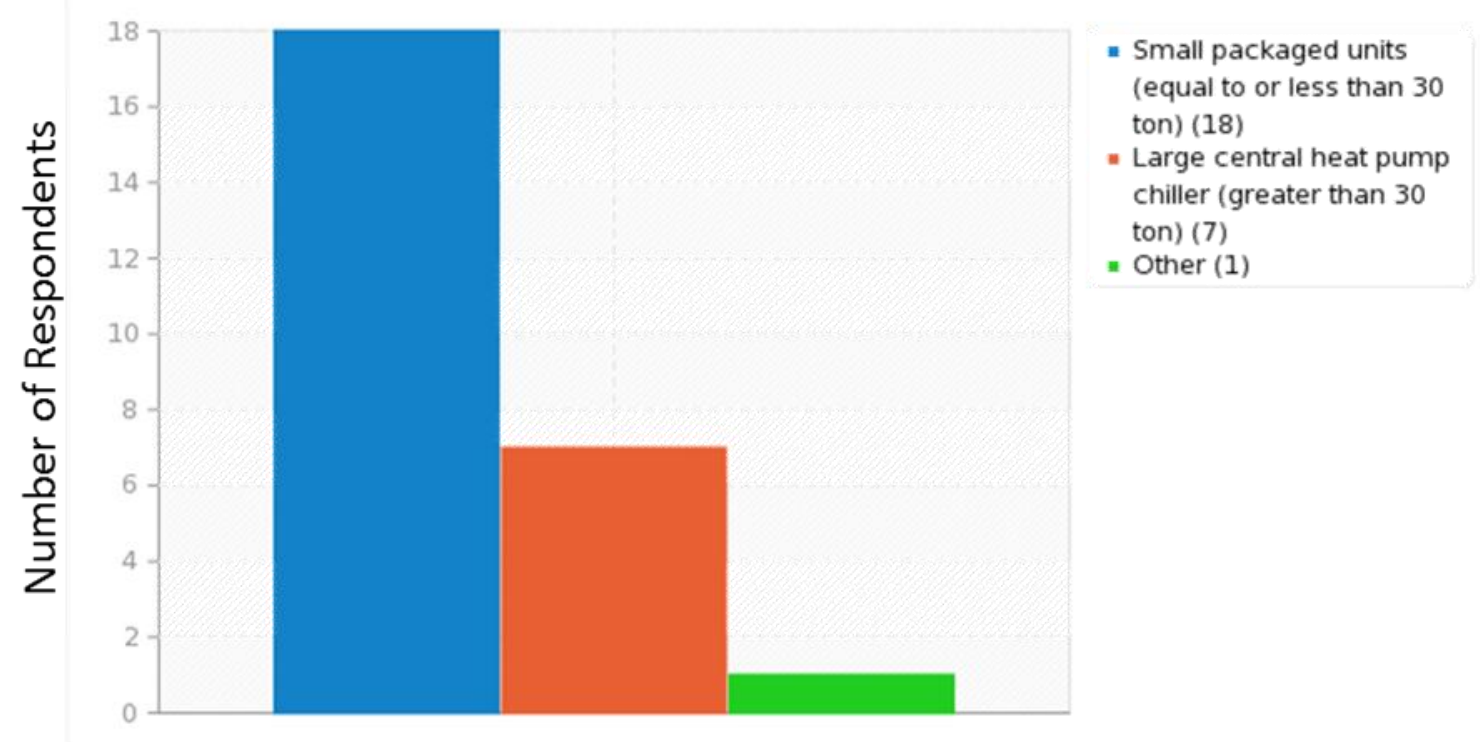

Fig. 7. Types of heat pump equipment used in the surveyed GHP systems.

\section{System configurations}

Two particular aspects of system configuration - space-conditioning system and domestic water heating integration-were surveyed. The types of space-conditioning systems being used in GHP systems are indicated in Fig. 8. Of the 21 responses to the survey, 14 (67\%) indicated that small packaged water source heat pumps (equal to or less than 30 ton) were used to directly condition spaces in the building. Eleven $(52 \%)$ and seven $(33 \%)$ respondents indicated that air-handling units with variable air volume (VAV) box and fan coil units were used, respectively, to provide space conditioning. Only one respondent $(5 \%)$ indicated radiant floors (heating) or chilled beams were used for space conditioning. It appears that 


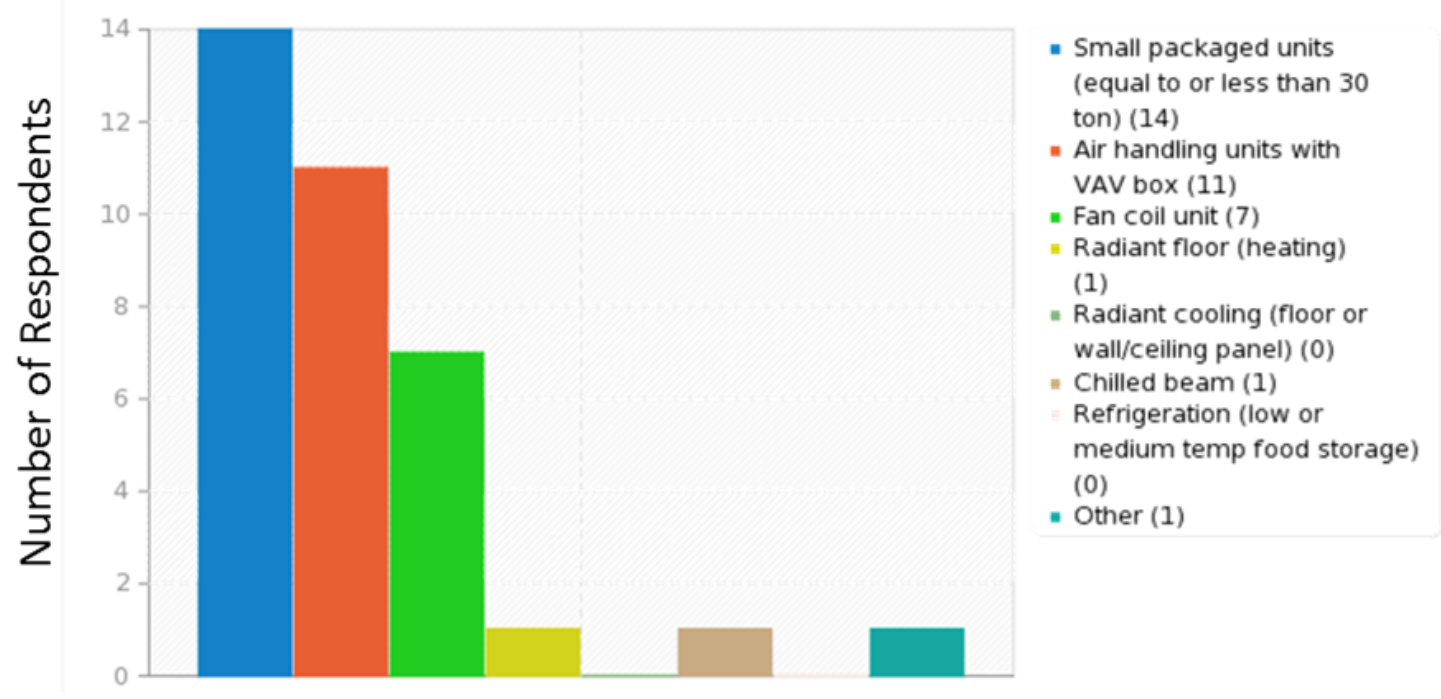

Fig. 8. Survey results for space-conditioning systems used in GHP systems.

small packaged water source heat pumps - which could be either stand-alone units in residential applications or connected with other water source heat pumps through a common water loop in commercial applications - are widely used in GHP systems. Other GSHP systems use central heat pump chillers, in which case additional devices such as VAV boxes, fan coil units, radiant floors, or chilled beams must be installed in the building.

Figure 9 shows survey results for domestic water heating integration with GHP systems. Only 8 of the 21 respondents indicated that the GHP systems had been used for water heating. These respondents estimated that, on average, $23 \%$ of GHP systems were used either to preheat water with a desuperheater, or to provide full hot water service with a dedicated GHP system or a dual-function system (one that supplies hot water or space heating/cooling as determined by a control system).

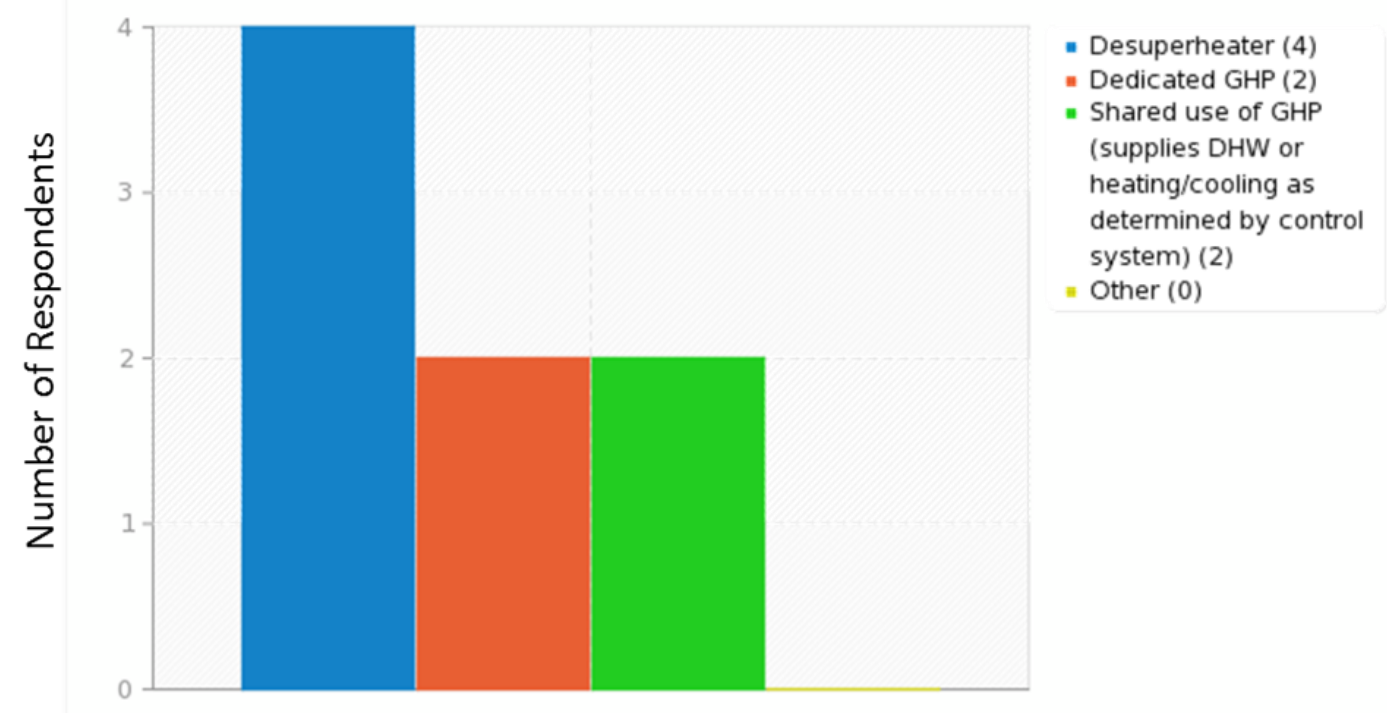

Fig. 9. Survey results for how GHP systems are used for domestic water heating. 


\subsubsection{Consumer Satisfaction with Installed GHP Systems}

As shown in Fig. 10, 10 of the 14 survey respondents (72\%) who are federal employees (consumers of the GHP systems) indicated that they were very satisfied or somewhat satisfied with the GHP systems installed in their facilities. Only one respondent (7\%) was somewhat unsatisfied with the GHP system. The remaining three respondents $(21 \%)$ were neither satisfied nor unsatisfied with the GHP system or had no opinion on it.

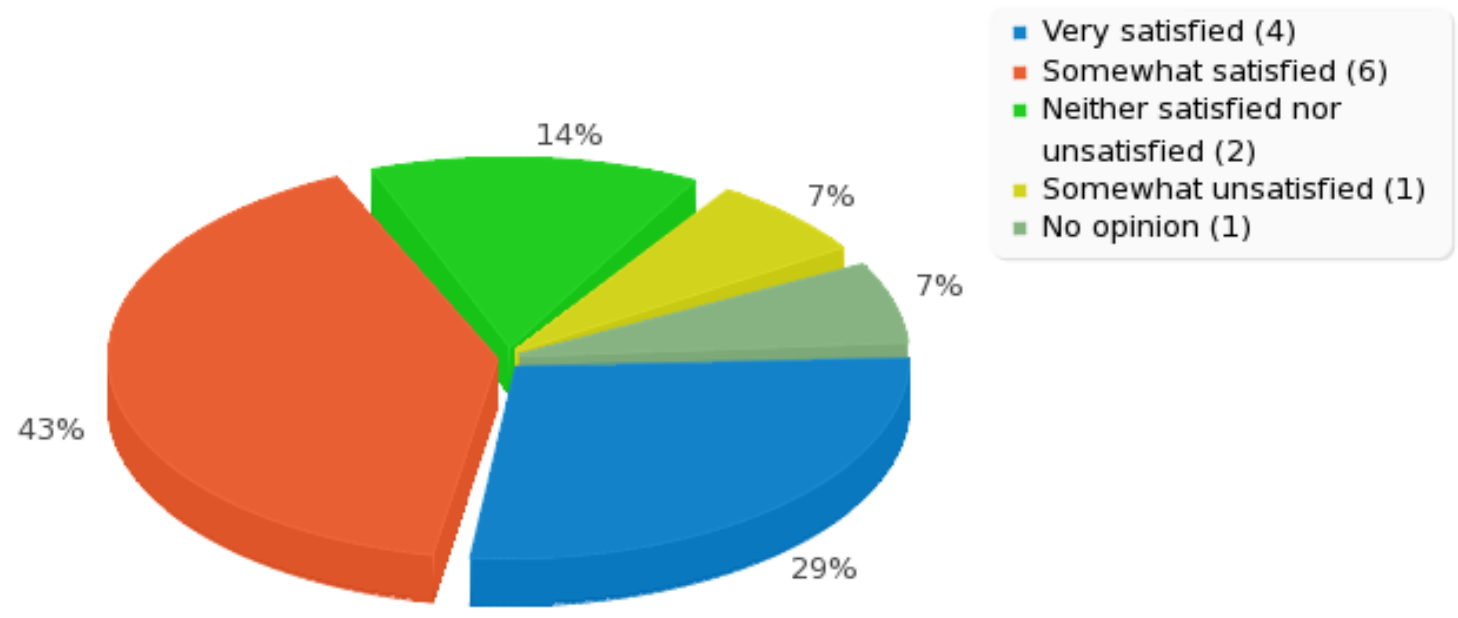

Fig. 10. Overall satisfaction level with regard to the GHP systems in the surveyed facilities.

Reasons for dissatisfaction identified by the survey respondents include (1) lower than expected operating efficiency and water problems due to changes made by the contractor to reduce cost, (2) high initial cost and low performance due to poor geology, (3) humidity problems due to inappropriately selected heat pumps, and (4) insufficient cooling and heating capacities due to underestimated loads.

The survey further asked the respondents to provide input on the satisfaction level of several specific aspects of the GHP systems. More than 50\% of the respondents were satisfied (either very satisfactory or satisfactory) with all the specified aspects except maintenance cost (Fig. 11). The top four aspects with which not all respondents were satisfied include (indoor) thermal comfort, maintenance cost, initial cost, and cooling capacity. However, no specific aspect received more than a $25 \%$ dissatisfaction rate.

More than half (52\%) of the survey respondents were satisfied with the initial cost of GHP systems. This number is higher than expected, since other studies indicated that high initial cost is the biggest barrier preventing wider adoption of GHPs (Hughes 2008). This finding may be due to the fact that many GHP projects in the federal sectors have been financed through either a Utility Energy Service Contract (UESC) or an Energy Saving Performance Contract (ESPC), which help reduce or eliminate the initial cost burden to the federal facilities (DOD 2007). ${ }^{1}$

About $25 \%$ of the respondents were not satisfied with the maintenance costs of their GHP systems. However, almost the same number of respondents were very satisfied with this particular aspect of their GHP systems. This result suggests there is wide variation among maintenance costs of GHP systems in

\footnotetext{
${ }^{1}$ According to a DOD report (DOD 2007), 42\% and 38\% of total DOD's GHP capacity has been installed through UESCs and ESPCs, respectively.
} 


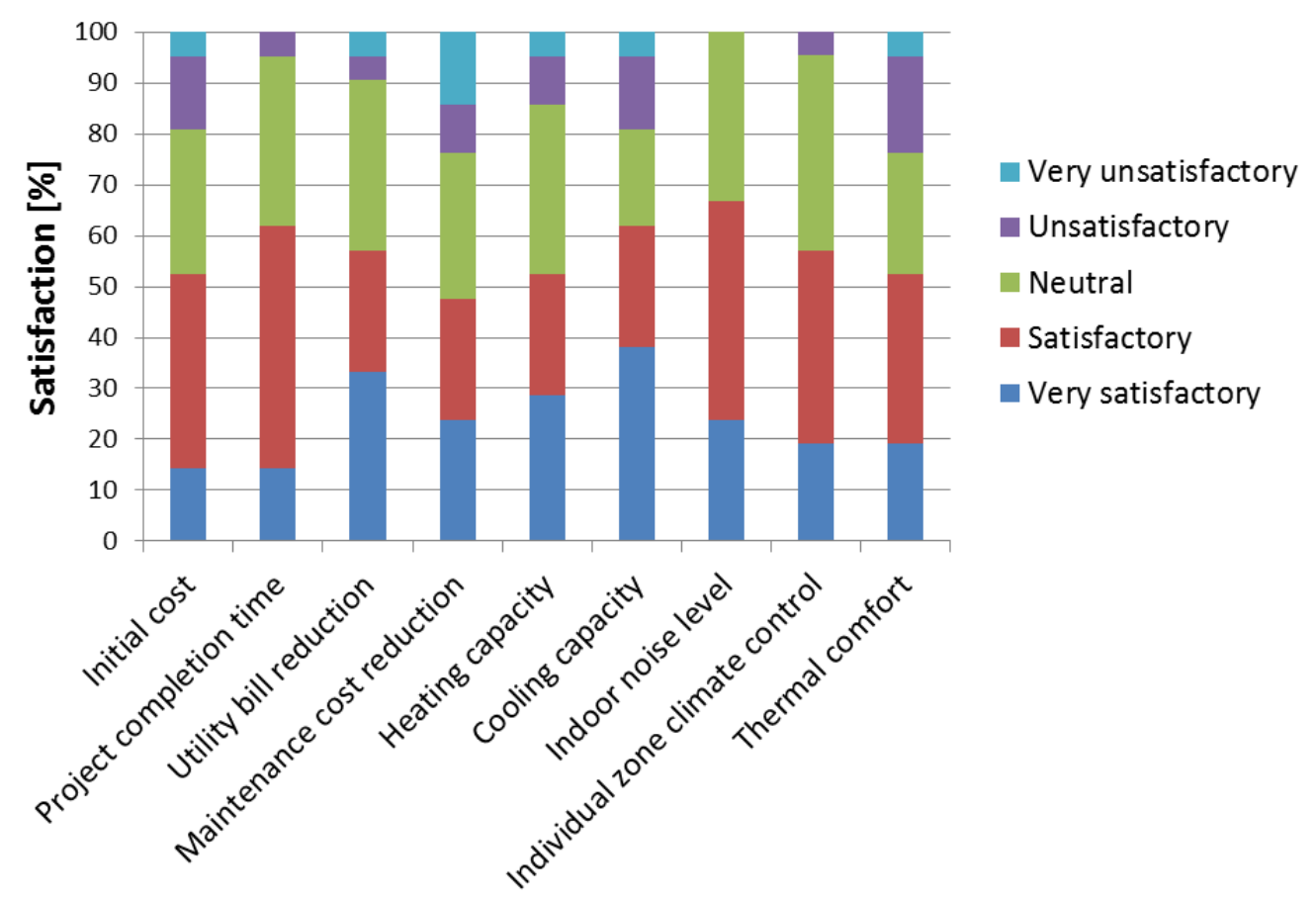

Fig. 11. Satisfaction level with regard to specific aspects of the surveyed GHP systems.

federal facilities. It is consistent with the conclusion of a previous survey on maintenance and service costs of commercial building GHP systems (Cane et al. 1998). That survey showed that maintenance and service costs varied from 7.32 cents/ $/ \mathrm{ft}^{2}$ to as much as $10.95 \mathrm{cents} / \mathrm{ft}^{2}$, depending on whether the work is done by in-house personnel or by an outside contracting organization.

\subsubsection{Common Causes of Malfunctioning GHP Systems}

According to the survey results, 10 of 21 respondents (47.6\%) indicated that they were aware of GHP systems in their facilities that were not functioning properly. The respondents also provided input on the estimated contributions of various causes to the malfunctioning of the GHP systems. In addition to the causes listed in the survey, the respondents identified the following three other causes:

1. Water leakage in the closed-loop system due to blockages in circuit setters and heat exchangers caused by loose scale resulting from hard makeup water.

2. Failure of dry fluid coolers used in hybrid GHP systems due to operator error and freezing damage.

3. Limited access to maintain the small units installed above the ceiling.

As shown in Fig. 12, unqualified designer, unqualified installer, and poor design tool appear to be the three major causes to the malfunctioning GHP systems.

The survey also asked which phases of a GHP project need to be improved, and in which areas the improvements are needed. Figures 13 and 14 summarize the responses to these two questions, respectively. Design and commissioning are the two phases in which the majority of the respondents perceived a need for improvement (Fig. 13). 


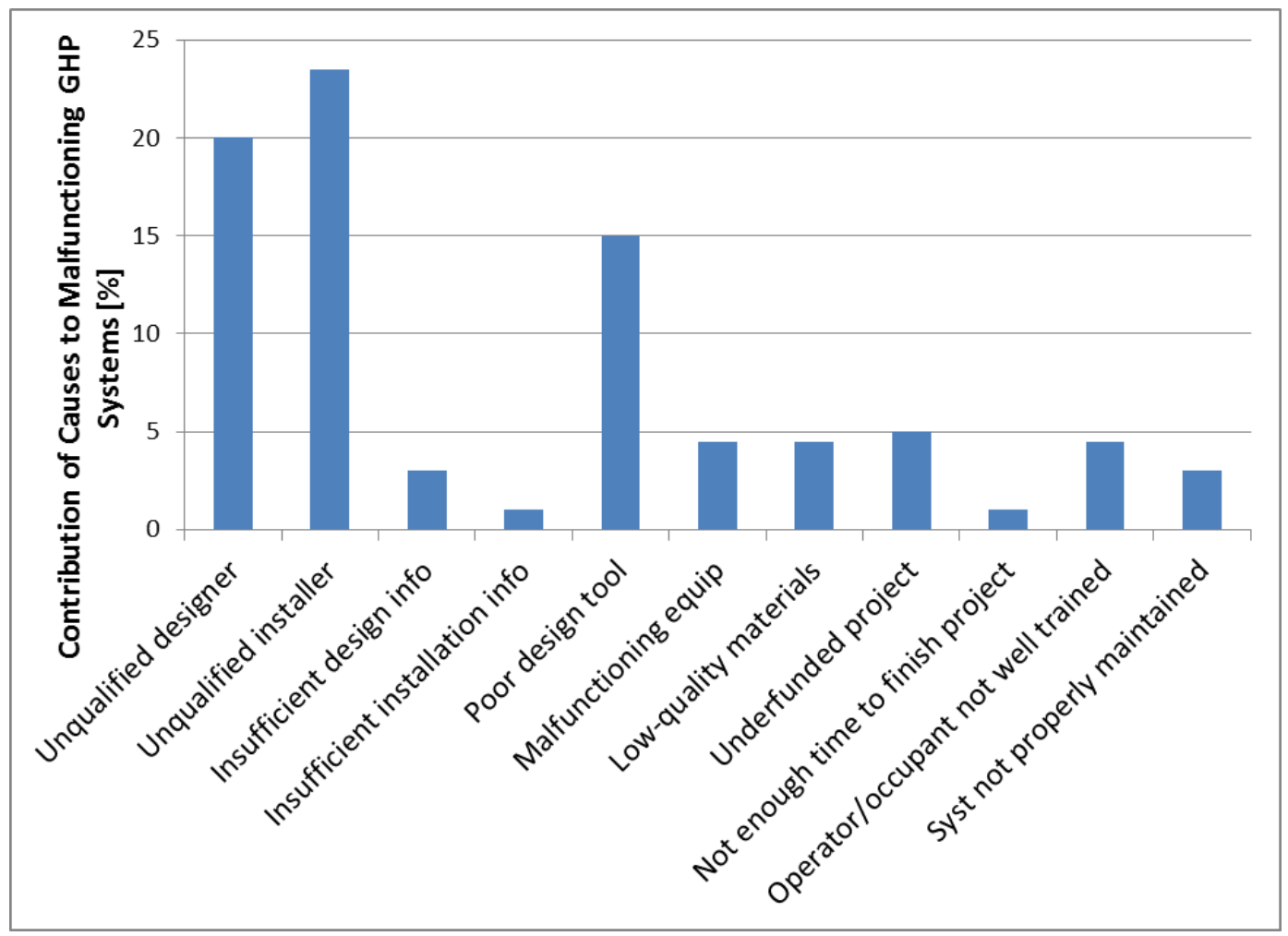

Fig. 12. Contribution of various causes to malfunctioning GHP systems.

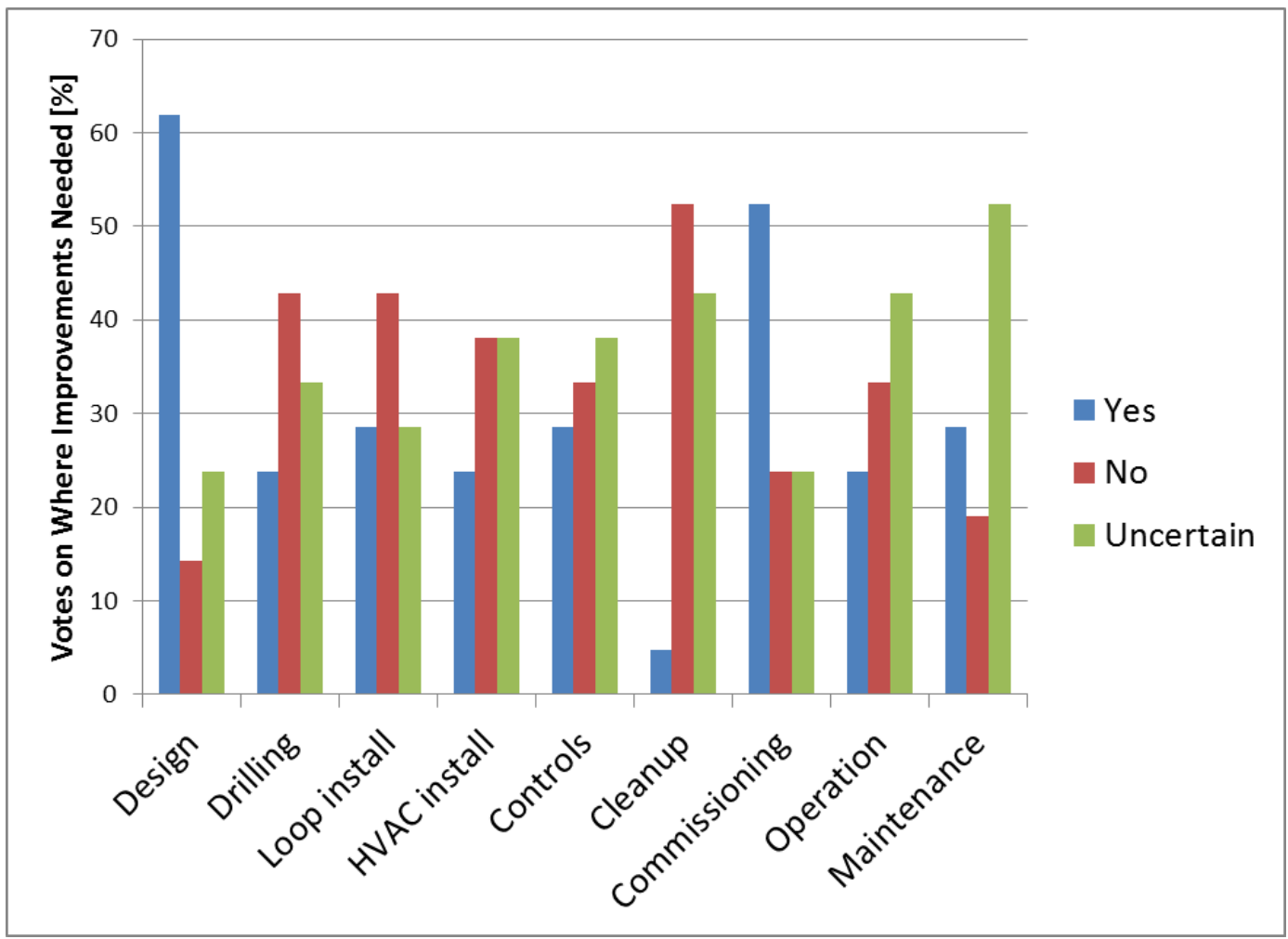

Fig. 13. Survey results on which phases of a GHP project need improvement. 
The results shown in Fig. 14 indicate that the improvements should focus on the quality of these two phases. In addition to the areas specified in the survey, the respondents suggested other areas in which improvement is needed, including placement of the heat pump unit to facilitate maintenance, integration of the control system, effective involvement of commissioning, sizing of GHX, verification of grouting, assessment of best solution for GHP systems, and capability for drilling deep boreholes. A complete list of the suggested areas for improvement is available in Appendix A.

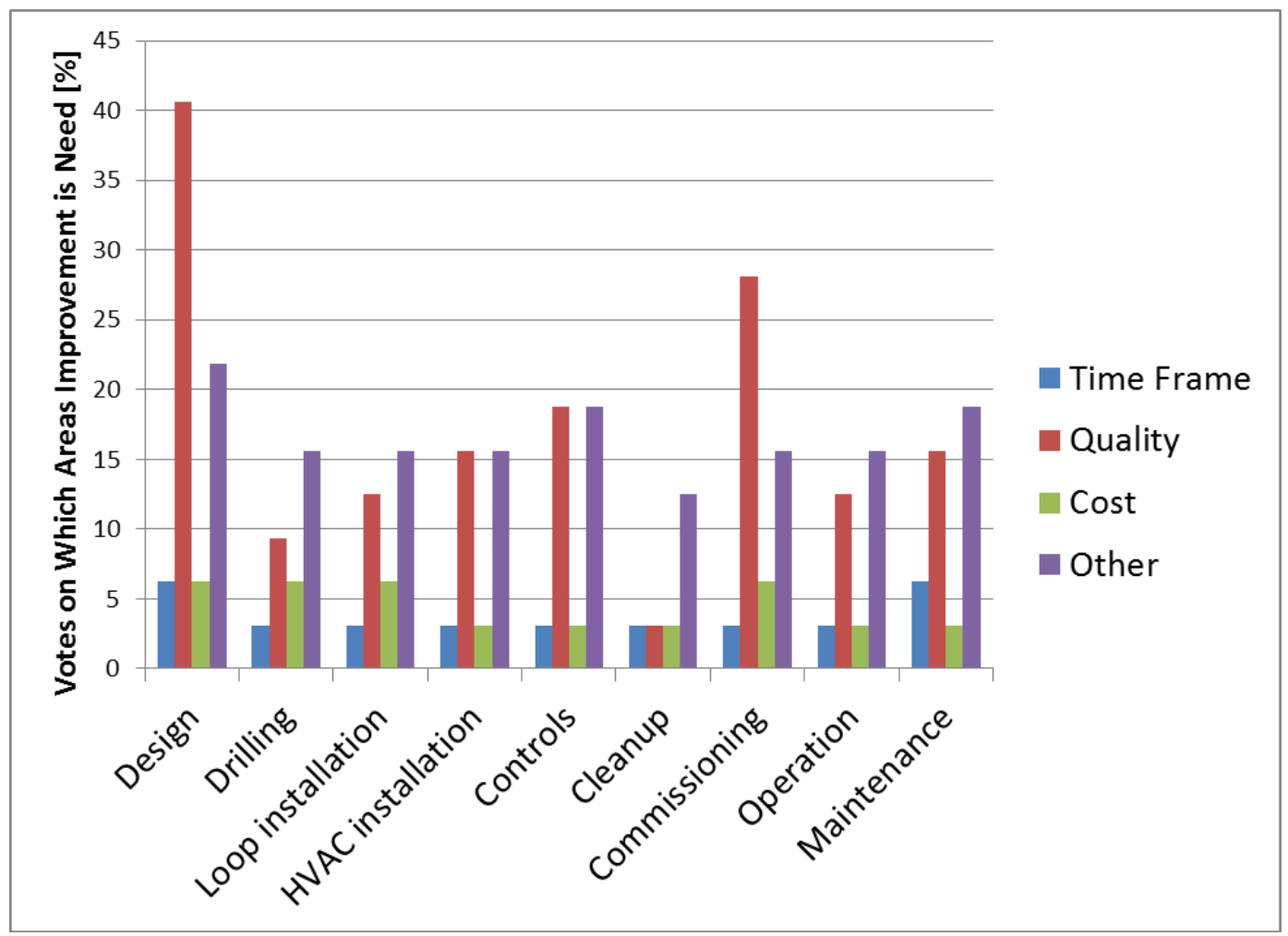

Fig. 14. Survey results on where improvements are needed in each phase of a GHP project.

\subsubsection{Best Practices to Deliver High-Quality GHP Systems}

Figure 15 summarizes input from survey respondents on best practices to deliver high-quality GHP systems. The respondents strongly agreed on the following practices:

- Hire qualified professionals

- Get required design and installation information

- Use appropriate design tools

- Specify good-quality equipment and materials

- Ensure enough budget/time

The respondents also recommended several other practices, including a holistic system approach that involves all stakeholders in the design of GHP systems to optimize energy savings and minimize lifecycle maintenance cost, accurate heating and cooling load calculations (for both peak and annual cumulative loads), avoiding oversizing equipment (especially pumps), and avoiding the use of dry fluid coolers. A complete list of the recommended practices is available in Appendix A. 


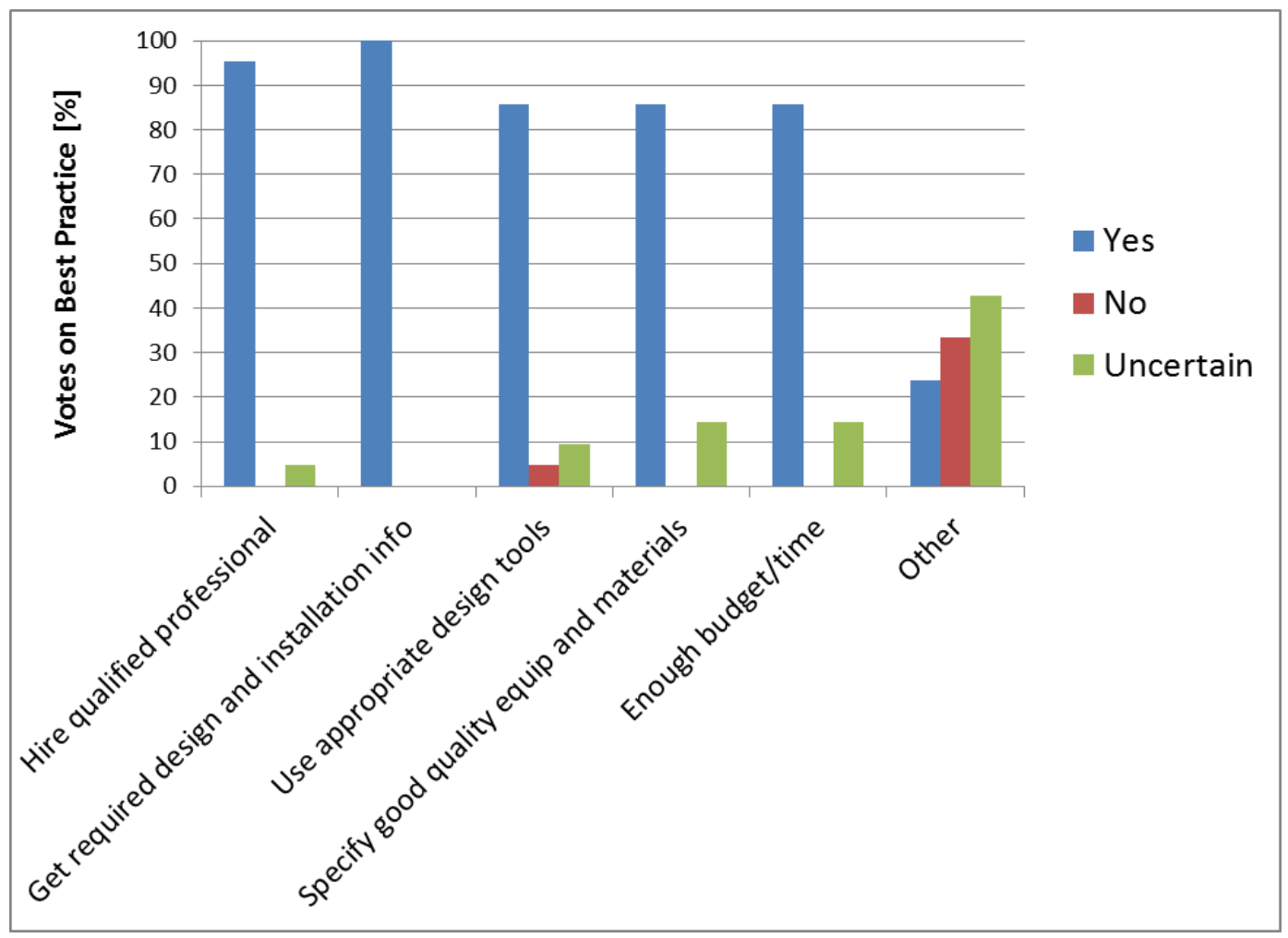

Fig. 15. Recommended best practices to deliver high-quality GHP systems.

\subsubsection{Disciplines Involved in GHP Projects}

As shown in Fig. 16, survey respondents indicated that each of the pre-defined GHP disciplines (Appendix C) was involved in implementing one or more of the surveyed GHP systems. The participation of a GHP design engineer, vertical borehole driller, and mechanical system installer was confirmed by more than $50 \%$ of the respondents. On the other hand, less than $10 \%$ of the respondents confirmed the participation of the following disciplines: horizontal directional driller, water well designer, standing column well driller, water well pump installer, and GHP system regulator. Significant numbers of respondents were uncertain whether a particular GHP discipline was part of the GHP project. These results indicate that (1) the disciplines involved in a particular GHP project may differ depending on the characteristics of the project, especially the heat sink and source used in the GHP system, and (2) there are not widely accepted definitions for the disciplines involved in GHP projects.

A third of the survey respondents also provided their opinions as to which disciplines need certification and what the required certifications should be. In summary, they suggested that a designer of GHP systems must be certified and have prior work experience, and that there must be a certified master driller on site with prior experience in GHP system installations. Some respondents emphasized that the designer should be a registered Professional Engineer (PE), preferably with the Certified Geoexchange Designer (CGD) certification, or should at least have some GHP system design experience and be teamed with an IGSHPA certified driller/installer. Additionally, a few respondents indicated that some states require that the designer of a GHP system must have CGD or PE certification. 


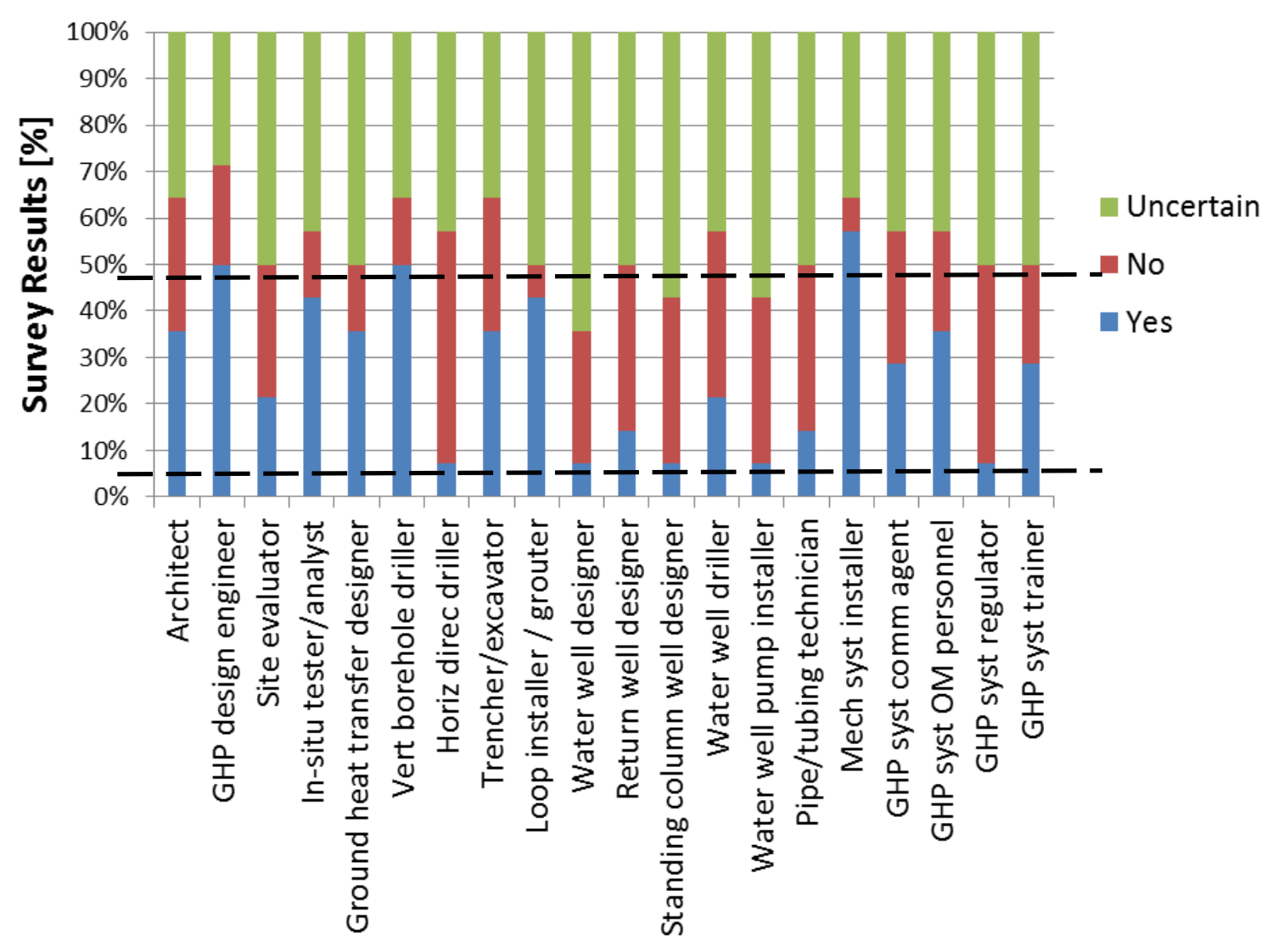

Fig. 16. Survey results on disciplines that helped the federal facilities implement the GHP systems.

\subsubsection{Qualifications of Disciplines}

Figure 17 summarizes the feedback from the respondents regarding qualifications of professionals who consistently deliver high-quality GHP systems. The majority of the respondents (> 60\%) agreed upon the following qualifications:

- Higher education (e.g., beyond high school degree)

- Training by industry experts

- Many years of experience in GHP projects

- Maintaining appropriate certifications and licenses

However, most respondents were uncertain whether higher pay for service is closely related to high quality of the delivered GHP system. 


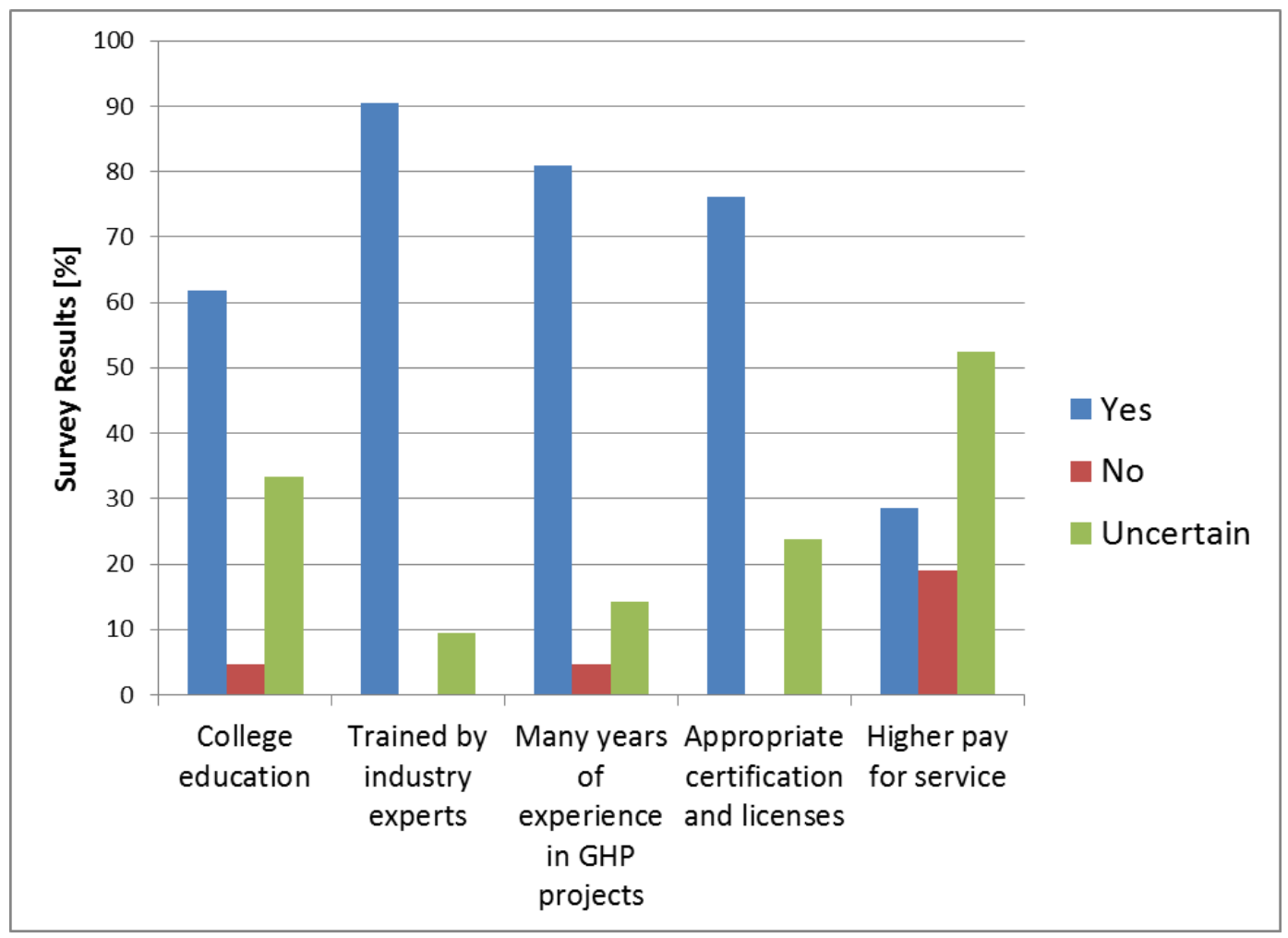

Fig. 17. Survey results on qualification requirements for GHP disciplines.

\subsubsection{Key Barriers Preventing Wider Adoption of GHP Systems}

Figure 18 summarizes the survey results on barriers that prevent wider adoption of GHP systems in federal facilities. More than $60 \%$ of respondents agreed that major barriers include lack of experienced designers and installers, high initial cost, and lack of awareness of GHP technology. Additionally, 38\% and 19\% of respondents, respectively, thought that lack of proof of estimated benefits and difficulties in construction scheduling and management are major barriers. Other barriers identified by the survey respondents include Army procurement regulations, lack of complete load profiles and false heating and cooling loads, poor geological conditions, lack of an overall HVAC system package, and high cost created by insistence upon expensive closed-loops and the consequent need for supplemental heating. A complete list of other barriers identified by survey respondents is available in Appendix A. 


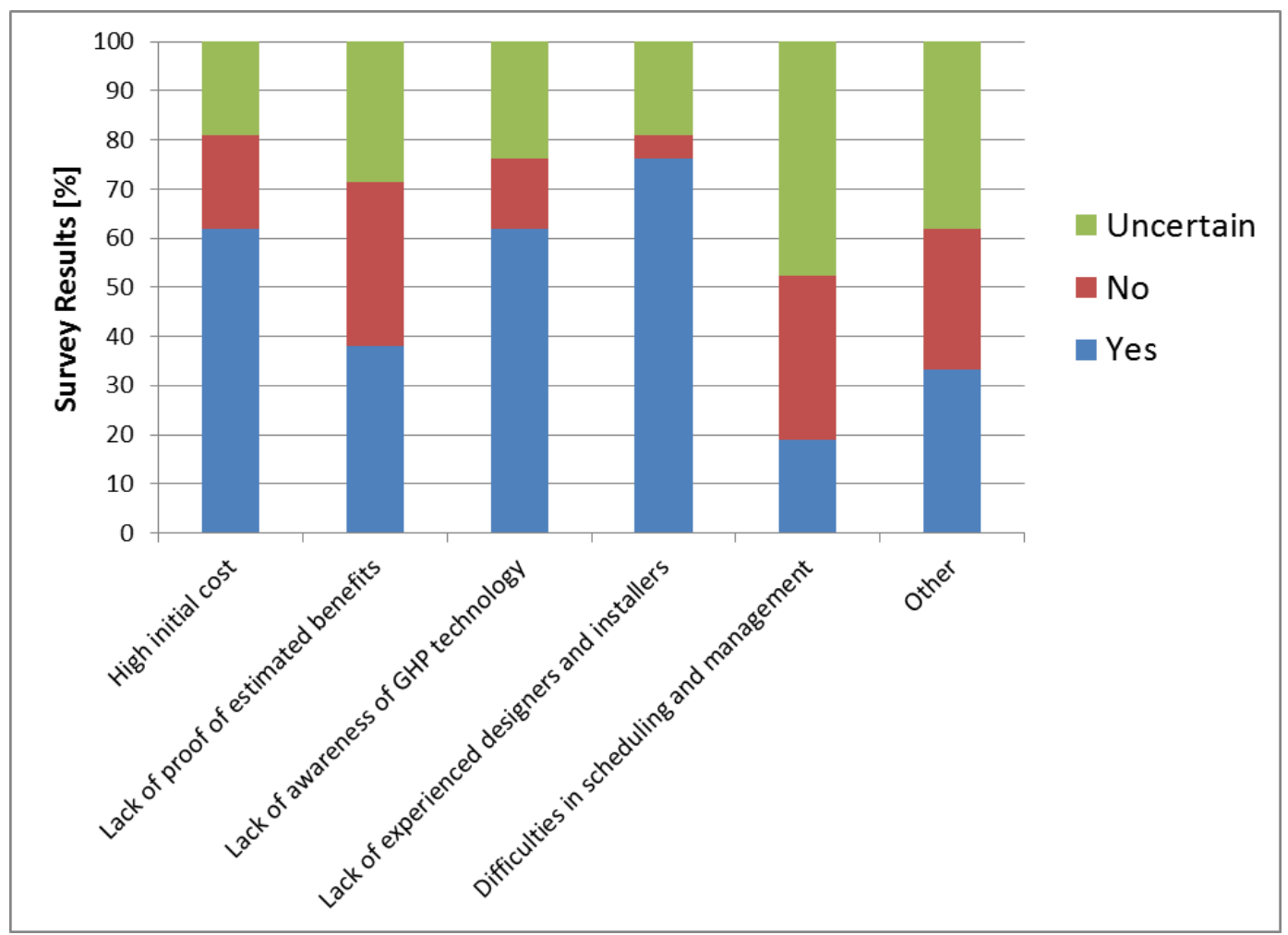

Fig. 18. Survey results on barriers preventing wider adoption of GHP systems in federal facilities.

\subsection{RESULTS FROM THE SURVEY REGARDING MINIMUM QUALIFICATIONS}

This survey was designed to collect information from as many US GHP industry stakeholders as possible regarding

- Classification and definition of disciplines typically involved in GHP projects

- Minimum qualification requirements for each pre-defined GHP discipline, including education, years of experience, and currently required licenses and certifications.

\subsubsection{Profile of Survey Respondents}

The total number of completed responses to the survey was 39. The survey respondents represent 19 of the 20 pre-defined GHP discipline classifications, as indicated by their responses to the survey question "Which of these GHP discipline classifications describes your role(s)?" Respondents' responses are summarized in Fig. 19. 


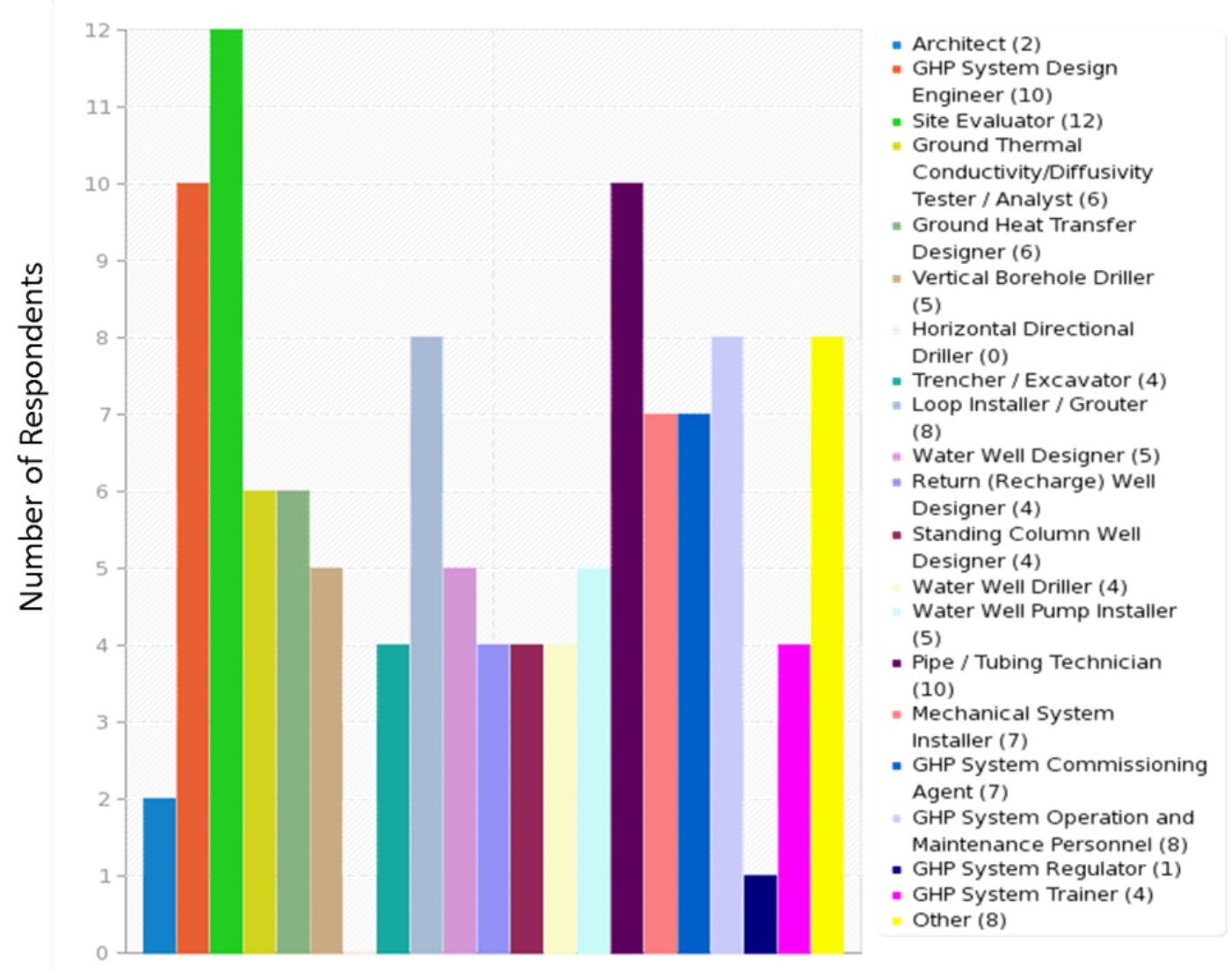

Fig. 19. GHP disciplines represented by survey respondents.

The only discipline not represented is Horizontal Directional Driller. The top five categories selected by the survey respondents to describe their disciplines are Site Evaluator (12 of 39), Pipe/Tubing Technician (10 of 39), GHP System Design Engineer (10 of 39), Loop Installer/Grouter (8/39), and GHP System Operation and Maintenance Personnel (8/39). Respondents were allowed to select multiple disciplines to describe themselves. The total count of identified disciplines in the survey results exceeds the total number of survey respondents, indicating that many respondents have experience in several of the predefined disciplines.

The survey respondents also include representatives of heat pump manufacturers, associations of GHPrelated professions, state governments, and utilities.

\subsubsection{Opinions Regarding the Pre-defined Disciplines in the GHP Industry}

Of the 39 survey respondents, 7 commented on the pre-defined GHP disciplines in their responses. The numbers of responses pertaining to each definition are graphed in Fig. 20. Table 3 shows the pre-defined classifications and their definitions, as presented to survey respondents, and survey respondents' comments. 


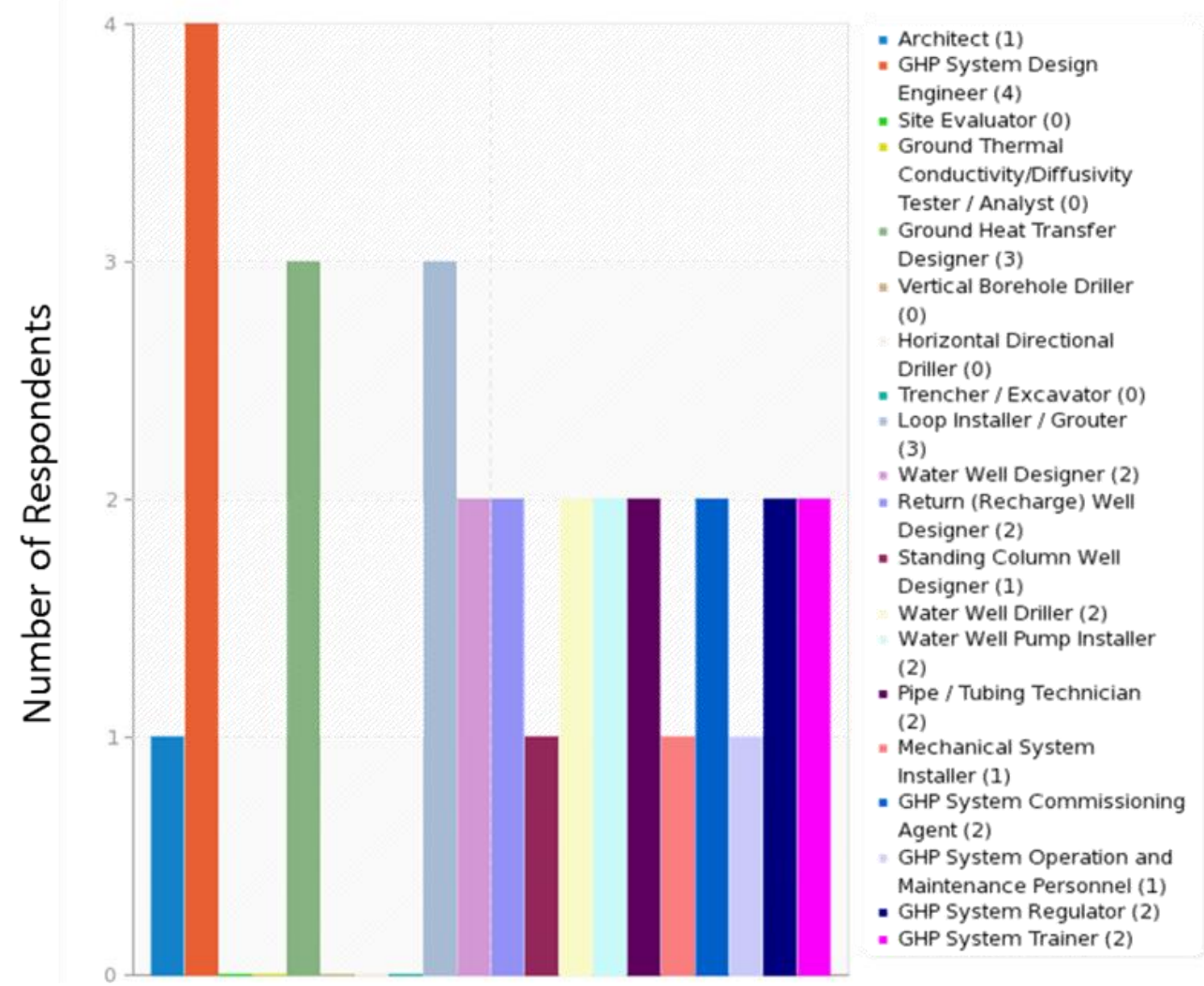

Fig. 20. Number of survey respondents who commented on the pre-defined GHP disciplines.

The responses indicate a need to clarify the classification and description of some disciplines, including GHP System Design Engineer, Ground Heat Transfer Designer, and Loop Installer/Grouter. One comment was "add a design/build category for projects that do not require PEs and stamped drawings." Another comment strongly suggested merging the design of the HVAC system and GHX to avoid integration errors and potential failure of GHP systems resulting from the limited knowledge of both parties. One comment suggested separating the Loop Installer and Grouter disciplines, since they "are two different jobs, and a loop installer may not be or need to be a grouter. For example, horizontal loops don't require grout unless drilled." It was also suggested that the Loop Installer and Pipe/Tubing Technician disciplines be combined.

A few respondents commented that there are "too many classifications on the list," and that the Water Well Driller, Water Well Designer, and Water Well Pump Installer should be combined into one discipline or should not be included in the list since they are "covered by National Ground Water Association certifications and [have] nothing to do with geothermal HVAC other than providing the water used for an open loop system well." 
Table 3. Pre-defined GHP discipline classifications and comments by survey respondents

\begin{tabular}{l} 
Pre-defined classifications \\
\hline Architect: design of overall project architectural \\
considerations, including facility siting and use, aesthetics, \\
regulatory compliance, etc. \\
GHP System Design Engineer: design and specification \\
of the entire GHP system including both the GHX or open \\
loop well(s) and the balance of the GHP system; may \\
subcontract appropriate tasks, for example: \\
- site evaluation to a qualified Site Evaluator \\
- design and specification of GHX to a qualified Ground \\
Heat Transfer Designer \\
- design of open-loop supply, return, and standing column \\
well(s), including physical location(s), to a qualified \\
Water Well Designer, Return Well Designer, or Standing \\
Column Well Designer.
\end{tabular}

Site Evaluator: investigation and evaluation of site environmental conditions, including one or more of the following: safety, regulatory due diligence, hydrogeology, water quality, aquifer temperature change, injection well and/or surface water discharge requirements, and potential impacts to other groundwater and/or GHP system users.

\section{Ground Thermal Conductivity/Diffusivity Tester / \\ Analyst - closed loop only: determination and/or verification and analysis of thermal properties of geological formations from short-term field tests of previously installed vertical GHXs, drilling logs, etc.}

Ground Heat Transfer Designer: design of one or more types of ground heat transfer, including

- closed loop only - ground-coupled heat exchangers (vertical borehole, horizontal excavation or directional drilling)

- closed loop only — surface water heat exchangers

- open loop only - groundwater well and/or standingcolumn well heat transfer

Vertical Borehole Driller-closed loop only: construction of borehole(s) for vertical ground-coupled heat exchangers

\section{Horizontal Directional Driller-closed loop only:} construction of directional drilling for ground-coupled heat exchangers
How many classifications do we need?

Make a designer a designer. Don't call it by 3 different names.

Add a design/build category for projects that do not require PEs and stamped drawings. Many of the designers that have been successful for years are not PEs-myself included.

To include ALL of the HVAC system from earth to delivery terminal in the building - a COMPOSITE design is always mandated. All too often the geo stops at the building wall - integration errors made by ignorance on both parties, and the geo universally get the "blame." There are too many classifications on the list at present - this level of fragmentation leads to a high probability of failure/problems.

There should be a distinctive classification for pump and reinjection technology, controls technology, vfd technology, etc.

Again with the redundant designer . . . there is no reason for 20 different job classifications here.

Training should include pump and reinjection technology, controls technology, vfd technology, etc.

Change the definition and include design of the HVAC system or add HVAC designer class and change the current definition removing "entire" from design and specification of the entire GHP system including both the ground. 
Table 3. Pre-defined GHP discipline classifications and comments by survey respondents (continued)

\begin{tabular}{cl}
\hline Pre-defined classifications & Comments on classifications \\
\hline
\end{tabular}

Trencher / Excavator: construction of GHP system trenching and/or excavation

Loop Installer / Grouter—closed loop only: installation of one or more types of heat exchangers, including groundcoupled heat exchangers (vertical or horizontal), surface water heat exchangers, etc., as well as system integrity testing, flushing and purging, flow and balance testing

Water Well Designer-open loop only: design of production well(s) and well field operation, including well location(s), water quality, and flow requirements for the GHP system

Return (Recharge) Well Designer - open loop only: design of return (recharge) well(s) and the return well operation, including evaluation of the potential for the precipitation of dissolved minerals and the deterioration of the recharge capacity over time.

Standing Column Well Designer-open loop only: design of standing column well(s) and well fields, including water quality and flow requirements for the GHP system, and the potential use of bleed water to enhance performance.

Water Well Driller -open loop only: construction, development, completion and protection of physical water supply well, return well, and/or standing-column well.

Water Well Pump Installer - open loop only: sizing, installation, service, and repair of water well pumping systems and related GHP equipment.
Grouting would seem to be a function of the vertical bore installer, not a separate classification.

Loop installer and Grouter are two different jobs and a loop installer may not be or need to be a grouter; i.e., horizontal loop don't require grout unless drilled.

Vertical Loop Installer/Grouter or Horizontal Loop Installer.

One well category is fine.

This is covered by NGWA certifications and has nothing to do with geothermal HVAC other than providing the water used for an open loop systemREMOVE.

One well category is fine.

This is covered by NGWA certifications and has nothing to do with geothermal HVAC other than providing the water used for an open loop systemREMOVE.

One well category is fine.

One well category is fine.

This is covered by NGWA certifications and has nothing to do with geothermal HVAC other than providing the water used for an open loop systemREMOVE.

One well category is fine.

This is covered by NGWA certifications and has nothing to do with geothermal HVAC other than providing the water used for an open loop systemREMOVE. 
Table 3. Pre-defined GHP discipline classifications and comments by survey respondents (continued)

\begin{tabular}{l} 
Pre-defined classifications \\
\hline Pipe / Tubing Technician: construction of approved pipe \\
and connections (joints/headers/manifolds, etc.) to \\
designated termination point (building wall, mechanical \\
room, or flow center, etc.) \\
- HDPE pipe fusion technician-construction of HDPE \\
pipe fusion connections \\
- PEX pipe joint technician-construction of PEX pipe \\
connections \\
- Copper pipe technician-construction of copper pipe \\
connections (DX systems) \\
- Other pipe / tubing technologies \\
Mechanical System Installer: installation of interior GHP \\
system, including heat pump equipment, pump system, \\
forced air and/or water distribution systems, and associated \\
control systems
\end{tabular}

GHP System Commissioning Agent: verification of GHP system installation, functionality, and capability of being operated and maintained to perform in conformity with applicable regulations and contract specifications, in addition to the system design intent

GHP System Operation and Maintenance Personnel: troubleshooting of GHP system problems, repair or replacement of malfunctioning components, routine maintenance to keep GHP systems operating within design specifications.

GHP System Regulator: adoption and enforcement of regulations governing design, installation, operation and maintenance of GHP systems

GHP System Trainer: delivery of training programs covering design, installation, operation and maintenance of GHP systems
Comments on classifications

Why should this be separate from "loop installer"?

HDPE ground installer or interior piping installer.

Training should include pump and reinjection technology, controls technology, vfd technology, etc.

Why is this separate from operator and maintenance? We don't need 20 categories.

There should be a distinctive classification for pump and reinjection technology, controls technology, vfd technology, etc. ... As well as training in the field for inspectors on the county and city level.

There should be a distinctive classification for pump and reinjection technology, controls technology, vfd technology, etc. ... The field of upcoming engineers, technicians and inspectors need to be vastly more educated on the basics of all kinds of geo, not just what used to work.

Why is this separate from operator and maintenance? We don't need 20 categories.

There should be a distinctive classification for pump and reinjection technology, controls technology, vfd technology, etc.

Use of more up to date information, there are great new books on the market about geothermal HVAC and yet the same old tired info is still being taught.

Require trainers to provide post-training support.

\subsubsection{Opinions on Minimum Qualification Requirements for GHP Disciplines}

Figures 21 and 22 illustrate survey respondents' opinions on the minimum requirements for education and years of experience, respectively, for each of the pre-defined GHP disciplines. As shown in Fig. 21, the majority of the survey respondents believe that a college degree should be required for Architect, GHP System Design Engineer, Site Evaluator, Ground Heat Transfer Designer, GHP System Commissioning Agent, and GHP System Trainer, but only a high school/GED degree or vocational degree is needed for qualification for the other disciplines. 


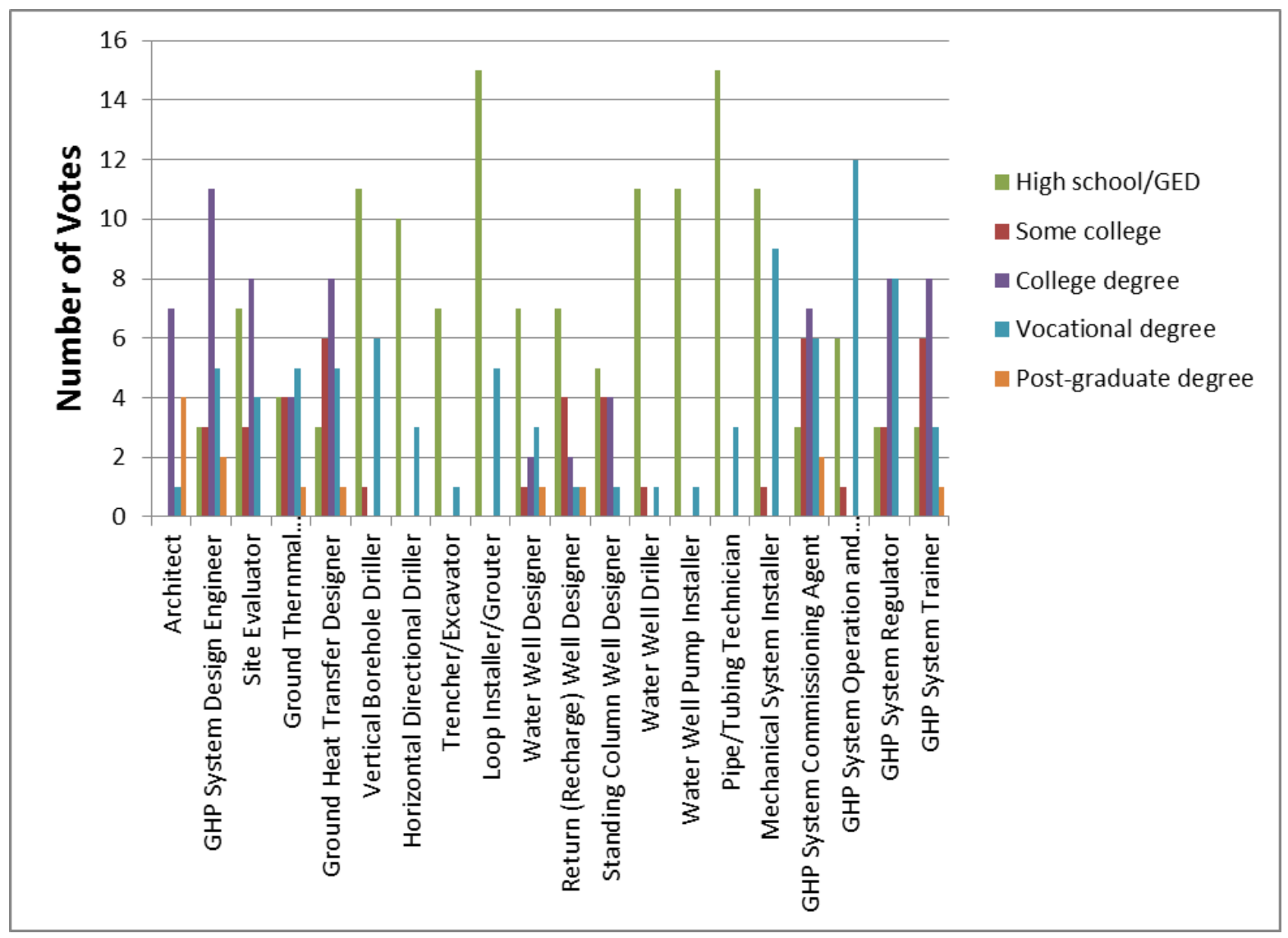

Fig. 21. Survey responses on minimum education requirements for the pre-defined GHP disciplines.

Survey participants think the disciplines requiring higher education also need more years of experience (Fig. 22). The majority of the survey respondents indicated that Architect, GHP System Design Engineer, Site Evaluator, Ground Heat Transfer Designer, Standing Column Well Designer, GHP System Commissioning Agent, GHP System Regulator, and GHP System Trainer should have more than 4 years of experience to be certified. On the other hand, survey respondents indicated that less than 1 year of experience should be required to perform the work in the disciplines of Trencher/Excavator, Loop Installer/Grouter, Pipe/Tubing Technician, and GHP System Operation and Maintenance Personnel. Survey respondents indicated that 1-4 years of experience should be required to be certified to perform the work in the remaining disciplines. 


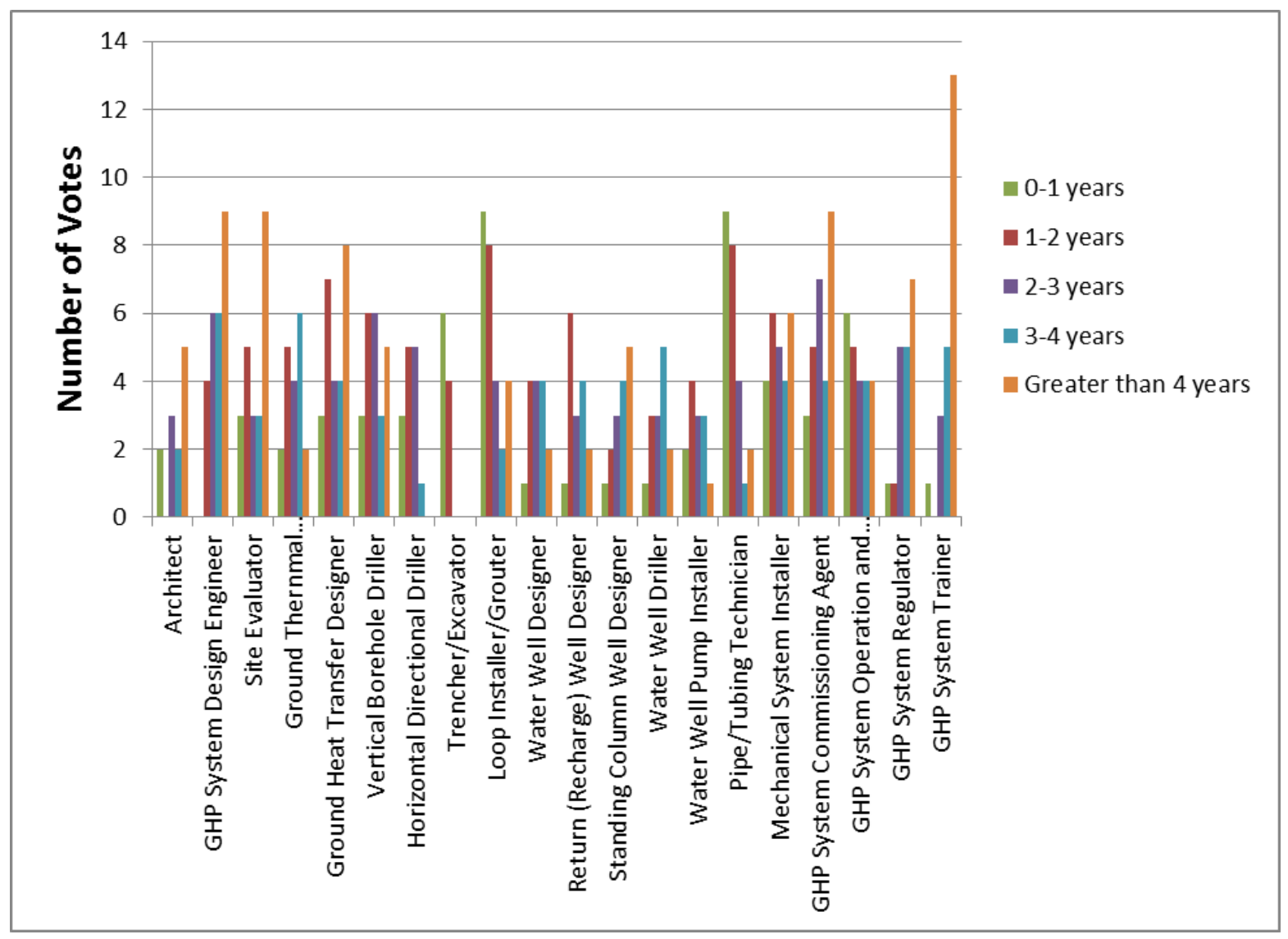

Fig. 22. Survey respondents' opinions on the minimum requirements for years of experience for the pre-defined GHP disciplines.

As can be seen in Fig. 23, which graphs survey responses regarding licensing or certification requirements for the pre-defined disciplines, opinions on this subject varied widely. A majority of survey respondents agreed on one particular licensing or certification requirement for only 1 of the 20 predefined disciplines, indicating that a GHP System Design Engineer should be an (IGSHPA) CGD. In addition, most survey respondents gave their opinions on the licensing or certification requirements for eight other disciplines, with more than $30 \%$ agreeing on at least one licensing or certification requirement for these disciplines: Ground Heat Transfer Designer, Vertical Borehole Driller, Loop Installer/Grouter, Pipe/Tubing Technician, Mechanical System Installer, GHP System Commissioning Agent, GHP System Operation and Maintenance Personnel, and GHP System Trainer. The survey respondents indicated that these disciplines should have certain licenses or certifications to perform their work, which arguably indicates a consensus on the required license or certification for these disciplines. The requirements that received most votes for these disciplines were CGD, IGSHPA Accredited Installer, IGSHPA Accredited Driller, and ACCA Certified HVAC technician.

There were significantly fewer responses regarding licensing or certification requirements for Architect and Trencher/Excavator. For Architect, a well-defined profession, the reason for the low response rate could either be that the available options in the survey are not applicable for an architect, or that an architect does not need any special licensing or certification to work on a GHP project. For Trencher/Excavator, it is more likely that the low response rate is an indication that there is no need to require any license or certification for this field. 


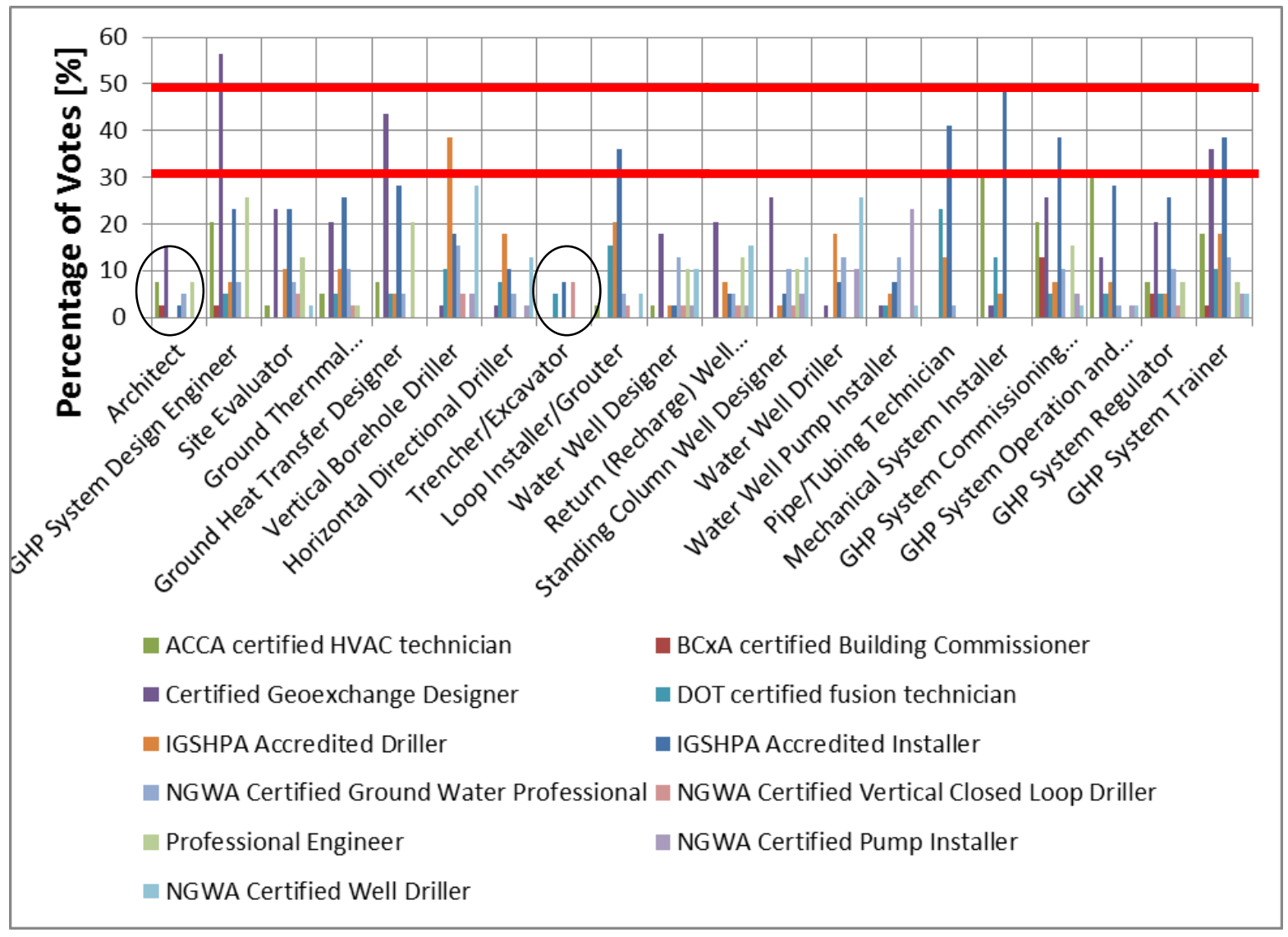

Fig. 23. Summary of all survey responses with regard to licensing or certification requirement for the pre-defined disciplines.

For the remaining nine disciplines, no single licensing or certification requirement received more than $30 \%$ of the votes, indicating that there is no strong consensus among the survey respondents on this question for these disciplines. The lack of consensus may be because (1) no widely accepted licensing or certification program has been developed for these disciplines (i.e., Site Evaluator, Conductivity/ Diffusivity Tester/Analyst, and GHP System Regulator) and/or (2) many of the survey respondents are not familiar with these disciplines (i.e., Water Well Designer, Return [Recharge] Well Designer, Standing Column Well Designer, Water Well Driller, Horizontal Directional Driller, and Water Well Pump Installer).

Table 4 summarizes the licensing or certification requirement that received the top three voting rates for each of the pre-defined disciplines. 
Table 4. Licensing or certification requirement with top three voting rates for each of the pre-defined disciplines

\begin{tabular}{|c|c|c|c|}
\hline Disciplines & Certifications with top three voting rates & $\begin{array}{c}\text { Percentage of } \\
\text { votes }(\%)\end{array}$ & Rank \\
\hline \multirow[t]{3}{*}{ Architect } & Certified Geoexchange Designer & 15.38 & 1 \\
\hline & ACCA-certified HVAC technician & 7.69 & 2 \\
\hline & Professional Engineer & 7.69 & 2 \\
\hline \multirow[t]{3}{*}{ GHP System Design Engineer } & Certified Geoexchange Designer & 56.41 & 1 \\
\hline & Professional Engineer & 25.64 & 2 \\
\hline & IGSHPA Accredited Installer & 23.08 & 3 \\
\hline \multirow[t]{3}{*}{ Site Evaluator } & Certified Geoexchange Designer & 23.08 & 1 \\
\hline & IGSHPA Accredited Installer & 23.08 & 1 \\
\hline & Professional Engineer & 12.82 & 2 \\
\hline \multirow{4}{*}{$\begin{array}{l}\text { Ground Thermal } \\
\text { Conductivity/Diffusivity } \\
\text { Tester/Analyst }\end{array}$} & IGSHPA Accredited Installer & 25.64 & 1 \\
\hline & Certified Geoexchange Designer & 20.51 & 2 \\
\hline & IGSHPA Accredited Driller & 10.26 & 3 \\
\hline & NGWA Certified Ground Water Professional & 10.26 & 3 \\
\hline \multirow[t]{3}{*}{ Ground Heat Transfer Designer } & Certified Geoexchange Designer & 43.59 & 1 \\
\hline & IGSHPA Accredited Installer & 28.21 & 2 \\
\hline & Professional Engineer & 20.51 & 3 \\
\hline \multirow[t]{3}{*}{ Vertical Borehole Driller } & IGSHPA Accredited Driller & 38.46 & 1 \\
\hline & NGWA Certified Well Driller & 28.21 & 2 \\
\hline & IGSHPA Accredited Installer & 17.95 & 3 \\
\hline \multirow[t]{3}{*}{ Horizontal Directional Driller } & IGSHPA Accredited Driller & 17.95 & 1 \\
\hline & NGWA Certified Well Driller & 12.82 & 2 \\
\hline & IGSHPA Accredited Installer & 10.26 & 3 \\
\hline \multirow[t]{2}{*}{ Trencher/Excavator } & IGSHPA Accredited Installer & 7.69 & 1 \\
\hline & DOT-certified fusion technician & 5.13 & 2 \\
\hline \multirow[t]{3}{*}{ Loop Installer/Grouter } & IGSHPA Accredited Installer & 35.90 & 1 \\
\hline & IGSHPA Accredited Driller & 20.51 & 2 \\
\hline & DOT-certified fusion technician & 15.38 & 3 \\
\hline \multirow[t]{4}{*}{ Water Well Designer } & Certified Geoexchange Designer & 17.95 & 1 \\
\hline & NGWA Certified Ground Water Professional & 12.82 & 2 \\
\hline & NGWA Certified Well Driller & 10.26 & 3 \\
\hline & Professional Engineer & 10.26 & 3 \\
\hline \multirow[t]{3}{*}{ Return (Recharge) Well Designer } & Certified Geoexchange Designer & 20.51 & 1 \\
\hline & NGWA Certified Well Driller & 15.38 & 2 \\
\hline & Professional Engineer & 12.82 & 3 \\
\hline \multirow[t]{4}{*}{ Standing Column Well Designer } & Certified Geoexchange Designer & 25.64 & 1 \\
\hline & NGWA Certified Well Driller & 12.82 & 2 \\
\hline & NGWA Certified Ground Water Professional & 10.26 & 3 \\
\hline & Professional Engineer & 10.26 & 3 \\
\hline
\end{tabular}


Table 4. Licensing or certification requirement with top three voting rates for each of the pre-defined disciplines (continued)

\begin{tabular}{|c|c|c|c|}
\hline Disciplines & Certifications with top 3 voting rates & $\begin{array}{l}\text { Percentage of } \\
\text { votes }(\%)\end{array}$ & Rank \\
\hline \multirow[t]{3}{*}{ Water Well Driller } & NGWA Certified Well Driller & 25.64 & 1 \\
\hline & IGSHPA Accredited Driller & 17.95 & 2 \\
\hline & NGWA Certified Ground Water Professional & 12.82 & 3 \\
\hline \multirow[t]{3}{*}{ Water Well Pump Installer } & NGWA Certified Pump Installer & 23.08 & 1 \\
\hline & NGWA Certified Ground Water Professional & 12.82 & 2 \\
\hline & IGSHPA Accredited Installer & 7.69 & 3 \\
\hline \multirow[t]{3}{*}{ Pipe/Tubing Technician } & IGSHPA Accredited Installer & 41.03 & 1 \\
\hline & DOT-certified fusion technician & 23.08 & 2 \\
\hline & IGSHPA Accredited Driller & 12.82 & 3 \\
\hline \multirow[t]{3}{*}{ Mechanical System Installer } & IGSHPA Accredited Installer & 48.72 & 1 \\
\hline & ACCA-certified HVAC technician & 30.77 & 2 \\
\hline & DOT-certified fusion technician & 12.82 & 3 \\
\hline \multirow{3}{*}{$\begin{array}{l}\text { GHP System Commissioning } \\
\text { Agent }\end{array}$} & IGSHPA Accredited Installer & 38.46 & 1 \\
\hline & Certified Geoexchange Designer & 25.64 & 2 \\
\hline & ACCA-certified HVAC technician & 20.51 & 3 \\
\hline \multirow{3}{*}{$\begin{array}{l}\text { GHP System Operation and } \\
\text { Maintenance Personnel }\end{array}$} & ACCA-certified HVAC technician & 30.77 & 1 \\
\hline & IGSHPA Accredited Installer & 28.21 & 2 \\
\hline & Certified Geoexchange Designer & 12.82 & 3 \\
\hline \multirow[t]{3}{*}{ GHP System Regulator } & IGSHPA Accredited Installer & 25.64 & 1 \\
\hline & Certified Geoexchange Designer & 20.51 & 2 \\
\hline & NGWA Certified Ground Water Professional & 10.26 & 3 \\
\hline \multirow[t]{3}{*}{ GHP System Trainer } & IGSHPA Accredited Installer & 38.46 & 1 \\
\hline & Certified Geoexchange Designer & 35.90 & 2 \\
\hline & ACCA certified HVAC technician & 17.95 & 3 \\
\hline
\end{tabular}

\subsubsection{Additional Comments from Survey Respondents}

In addition to answering the survey questions, several survey respondents provided valuable and insightful comments that can be grouped in the following categories: qualification requirements for GHPrelated disciplines, expectations of the national certification standard, and requirements for training and certification. These comments are summarized below. The complete list of all the comments is available in Appendix B.

\section{Qualification requirements for GHP-related disciplines}

- Experience and attendance at trade shows and driller conferences should be enough for drillers, as they are primarily equipment operators. 
- Every person engaged in the geothermal equipment installation should have at least 5 years of experience in the HVAC industry and at least some accreditations from IGSHPA and from any of the manufacturers of the geothermal systems. Also should be associated with any heat pump-related association, i.e., ACCA, etc.

- Broaden the requirements to recognize the need for a geo knowledge ACROSS the spectrum from design to final commissioning - and where appropriate to SIMPLY monitor (not a high-price BMS package) the first year of operation.

- Years of college, unless an engineering discipline, have nothing to do with geothermal design; making restrictions based on level of schooling is both unneeded and discriminatory.

- IGSHPA Accredited Driller should not be promoted, should not be included in this survey, and should be eliminated from the GHP industry. There is no real value in this accreditation.

\section{Expectations of the national certification standard}

- The national certification standard shall not include injection and standing-column wells that are illegal in some states.

- The national certification standard shall focus more on the specifics required to get a working design and less on "barriers to people entering this field."

- An objective federal accreditation unit shall be formed to certify the GHP-related professionals.

\section{Requirements for training and certification}

- NGWA believes that completing a fee-based course and then taking an open-book exam on the course content WITHOUT also having real-world demonstrated competency attested to by a third party is NOT an adequate qualification to open the subsurface and groundwater to the risk of contamination.

- Trainers need to be Professional Engineers or equivalent for credibility.

- Trainers shall provide necessary support to professionals who are new to the GHP industry; or a peerbased mentoring system shall be created.

- Some basic knowledge on duct work and installation techniques, such as accessibility, refrigerant charge, vibration isolation, filtration, etc. shall be included in the training criteria for a GSHP designer/installer.

\section{CONCLUSIONS}

Two surveys were conducted to collect information in support of the development of the first national certification standard for all primary personnel involved in the implementation of GHP systems. Sixty completed responses were received. Although the total response number is lower than expected, the results are nonetheless useful, since many of the survey respondents are either energy managers at federal facilities who have overseen many GHP projects, or industry stakeholders who have extensive experience in many disciplines required for implementing GHP systems. Survey results have been summarized in previous sections, and the main conclusions drawn from the two surveys are given in the following paragraphs. 


\section{Current status and customer perceptions with regard to existing GHP systems}

GHP systems have been implemented in federal facilities in the past 20 years at many different locations across the United States. The majority (72\%) of the surveyed federal facility energy managers is satisfied with their GHP systems, and $86 \%$ of the surveyed federal facilities have plans to expand installations of GHP systems in the next 5 years.

GHP systems have been used in at least 12 million $\mathrm{ft}^{2}$ of residential, commercial, and other buildings in federal facilities. On average, $46.44 \%$ of the GHP systems are installed in new construction and 53.56\% are installed in existing buildings.

The vertical closed-loop GHX is the most popularly used GHX (61\%) in the surveyed GHP systems, followed by standing column well (24\%), horizontal closed loop (7\%), ground water open loop (5.9\%), and surface water closed loop $(0.4 \%)$. Small packaged water source heat pumps are widely used in GHP systems, and central heat pump chillers are also used. On average, 23\% of GHP systems were used to either preheat water with a desuperheater or provide full hot water service with a dedicated GHP system or dual-function system (one that supplies hot water or space heating/cooling as determined by a control system).

More than $60 \%$ of respondents agreed that major barriers preventing wider adoption of GHP systems are lack of experienced designers and installers, high initial cost, and lack of awareness of GHP technology. Other barriers include lack of proof of estimated benefits, difficulties in construction scheduling and management, the complexity of Army procurement regulations, lack of complete load profiles and false heating and cooling loads, poor geological conditions, and high cost created by insistence upon expensive closed loops and the consequent need for supplemental heating.

\section{Best practices in the design and installation of GHP systems}

Consensus is reached on the following best practices for implementing high-quality GHP systems: (1) hire qualified professionals, (2) get required design and installation information, (3) use appropriate design tools, (4) specify good-quality equipment and materials, and (5) ensure enough budget/time. In addition, other practices are recommended, including a holistic system approach that involves all stakeholders in the design of GHP systems to optimize energy savings and minimize life-cycle maintenance cost, accurate heating and cooling load calculations (for both peak and annual cumulative loads), avoiding oversizing equipment (especially pumps), and avoiding the use of dry fluid coolers.

\section{Common causes of malfunctioning GHP systems and areas needing improvements}

According to the survey results, unqualified designers, unqualified installers, and poor design tools are the three major causes of malfunctioning GHP systems. The majority of the survey respondents believe that the quality of design and commissioning of GHP systems should be improved. The following areas have also been identified as needing improvement: placement of the heat pump unit, integration of the control system, effective involvement of commissioning, sizing of the GHX, verification of grouting, assessment of best solution for GHP systems, and capability for drilling deep boreholes.

\section{Classifications of disciplines required for implementing GHP systems}

The survey results indicated that a more practical classification of the disciplines involved in GHP projects is needed and that the descriptions of each discipline need to be clearly defined. This is thought to be the case especially for GHP System Design Engineer, Ground Heat Transfer Designer, and Loop Installer/Grouter. Many respondents suggested shortening the list of the disciplines that need GHP- 
specific certification to perform related work. It is also recommended that the design of the HVAC system and the GHX be merged to avoid the integration errors and potential failure of GHP systems resulting from the limited knowledge of both parties.

\section{Qualification requirements for the disciplines involved in GHP projects}

The majority of the survey respondents believe that a college degree should be required for Architect, GHP System Design Engineer, Site Evaluator, Ground Heat Transfer Designer, GHP System Commissioning Agent, and GHP System Trainer; but only a high school/GED degree or vocational degree is needed for qualification for the other disciplines.

According to survey responses, the disciplines requiring higher education also need more years of experience. The majority of the survey respondents indicated that Architect, GHP System Design Engineer, Site Evaluator, Ground Heat Transfer Designer, Standing Column Well Designer, GHP System Commissioning Agent, GHP System Regulator, and GHP System Trainer should have more than 4 years of experience to be certified. On the other hand, survey respondents indicated that less than 1 year of experience should be required to perform the work in the Trencher/Excavator, Loop Installer/Grouter, Pipe/Tubing Technician, and GHP System Operation and Maintenance Personnel disciplines. Survey respondents indicated that 1-4 years of experience should be required to be certified to perform the work in the remaining disciplines.

More than half of the respondents agreed that a GHP System Design Engineer should be an (IGSHPA) CGD. Some respondents emphasized that the designer should be a registered PE, preferably with CGD certification, or have at least some GHP design experience and be teamed with an IGSHPA-certified driller/installer. The survey results indicate that most respondents do not think it is necessary to have a GHP-specific certification for an Architect and Trencher/Excavator involved in GHP projects. However, there is no strong consensus among survey respondents regarding the certification requirement for a few disciplines, including Site Evaluator, Conductivity/Diffusivity Tester/Analyst, GHP System Regulator, Water Well Designer, Return (Recharge) Well Designer, Standing Column Well Designer, Water Well Driller, Horizontal Directional Driller, and Water Well Pump Installer. The survey responses arguably reached a consensus that at least one of the following certifications should be obtained and maintained by the other pre-defined disciplines: CGD, IGSHPA Accredited Installer, IGSHPA Accredited Driller, and ACCA Certified HVAC technician.

\section{REFERENCES}

DOD (US Department of Defense) 2007. Ground-Source Heat Pumps at Department of Defense Facilities, Office of the Deputy Under Secretary of Defense (Installations and Environment), US Department of Defense, Washington, D.C. 20585

Cane, D., A. Morrison, and C. J. Ireland 1998. "Maintenance and service costs in commercial building ground-source heat pump systems," ASHRAE Transactions 104 (2), 699-706.

Hughes, P. 2008. Geothermal (Ground-Source) Heat Pumps: Market Status, Barriers to Adoption, and Actions To Overcome Barriers, ORNL/TM-2008/232, Oak Ridge National Laboratory. 


\section{APPENDIX A: ADDITIONAL INFORMATION PROVIDED BY}

RESPONDENTS TO THE SURVEY OF FEDERAL EXPERIENCE ON GHP SYSTEMS 


\section{APPENDIX A: Additional Information Provided by Respondents to the Survey of Federal Experience on GHP Systems}

\section{Other options for ground heat exchangers}

- Cooling Tower

- The bulk of the installs are vertical wells but there are some horizontal wells in military family housing units along with select surface water systems

- Potable Water exchange / Closed Cell Cooling Tower

Types of buildings currently served by GHP systems

- Industrial

- $\quad$ Military--Primarily Office \& Maintenance

- This is across the Army and covers many types of buildings. I estimated approx. 10 Million sf of buildings across the Army are served by GHP systems. This is totally an estimate. My guess is that Fort Knox has approx. 6 million sf served from GHP systems and another 40 Army installations have approx. 100,000 sf each served from GHP systems.

- Classroom

- DOD TRAINING

\section{Reasons for dissatisfaction identified by the survey respondents}

- Poor performance. Geology in this area is poor for GSHP. Required in excess of 500-feet per ton of capacity. Package system not multistage so we are experiencing humidity problems. System sized for classroom, but unoccupied large percentage of the time.

- System has not met predicted operating cost efficiencies. System developed water problems. Contractor deviated from specifications in order to cut costs. Building was not properly commissioned.

- System was designed by engineering firm that apparently undersized the heating and cooling loads, at approximately $10 \mathrm{btu} / \mathrm{sqft}$ - with large out side doors and large air infiltration,

\section{Opinions from federal agencies as to which disciplines need to be certified}

- The majority of designs thru the Corps of Engineers require all designers to be registered Professional Engineers (P.E.s). Usually the specifications will reference criteria that are to be followed during the project. My impression is that mistakes are most often made when a holistic systems approach is not taken by considering both the well field and the building side HVAC systems together. To many times the mechanical engineers (though registered P.E.s) leave the well field design particulars up to the drilling contractor or the drilling contractor does not consider the building characteristics in his 
well field. On design/build projects I would prefer to have an IGSHPA certified driller/installer teamed up with a CGD designer or P.E. (with some geo-exchange design experience) during the very early stages of the design process. This way all stake holders are involved in a holistic, integrated design that optimizes the project energy savings along with minimizing life-cycle maintenance cost.

- Well field designer - CGD certification Well field installer needs to be certified, installer license from IGSHPA

- Design: The designer must be certified and have prior work experience. Install: Installation company (Drilling company) must have had prior geothermal drilling experience. If the state offers driller certification, Driller must be a certified Master Driller. Lateral loop installers must be a certified geothermal installer.

- We require designs by professional engineers. The designs are required to have energy modeling with well fields sized to the building load. We also require designers to use thermal conductivity analysis for sizing of well fields.

\section{Opinions from federal facilities as to which disciplines need to be certified}

- Well Field Design - CGD certification Well Field installation - Need IGSHPA certification

- Design: Certified by ASHREA Install: There must be a certified master driller onsite, loop manufacture must be certified by ASHRAE, prior experience

- WELL BORE FIELD,TESTING PROTOCOLS

- Designed by professional engineers. Thermal conductivities are required. Well field designs are required to be done with appropriate software.

- Massachusetts require CGD, AI or PE

- NH State PE

\section{Causes resulting in failure of GHP systems}

- We have had some failures due to leakage on a closed loop system with makeup water. Hard water over the years caused scale. Scale came loose during seasonal changes and blocked circuit setters and heat exchangers.

- We have had some hybrid system failures with dry fluid coolers due to operator error and freezing damage.

- We have had access issues with small units above the ceiling that caused difficulties with maintenance. 


\section{What needs to be improved for GHP projects?}

\begin{tabular}{|l|l|}
\hline \multicolumn{1}{|c|}{ Area } & \multicolumn{2}{c|}{ Comments on what needs to be improved? } \\
\multirow{2}{*}{ Design } & Loop Sizing \\
& Test well would have determined which system to use \\
\hline & Sizing \\
\hline Drilling & 2000 FOOT DRILL 10 INCH \\
\hline Loop installation & Wells were not grouted \\
\hline HVAC installation & Unit Placement for maintenance \\
\hline Controls & Integration w/geo \\
\hline Cleanup & \\
\hline Commissioning & Not involved \\
\hline Operation & Prompt evaluation of under-size \\
\hline Maintenance & \\
\hline
\end{tabular}

One of the respondents commented that "enough projects have been completed on Army installations for improvements to be made in all areas."

\section{Other barriers to wider application of GHP systems in federal facilities}

- Army procurement regulations.

- False heating and cooling loads oversize the system. Make for higher maintenance and possible failure. Customers unsatisfied in the end. Cost of project appears too high when oversized.

- Geology not ideal for heat transfer.

- USACE lack of design skills: efficiency knowledge

- Lack of overall HVAC system package - all too often Geothermal only translates to an earth coupling method. The earth coupling is ONLY a portion of the successful installation - the "geo" people do not understand or appreciate the "inside designer"

- High cost created by insistence upon expensive closed loop designs \& consequent need for supplemental fossil augmentation

- Lack of complete and verified heat loss and gains and load profile - an rigid heat loss analysis for the earth coupling designer

- Lack of accurate and responsible annual peaks and average heating, cooling and profile loads

\section{Other best practices for delivering a high-quality GHP project}

- My impression is that mistakes are most often made when a holistic systems approach is not taken by considering both the well field and the building side HVAC systems together. To many times the mechanical engineers (though registered P.E.s) leave the well field design particulars up to the drilling contractor or the drilling contractor does not consider the building characteristics in his well 
field installation. On design/build projects I would prefer to have an IGSHPA certified driller/installer teamed up with a CGD designer or P.E. (with some geo-exchange design experience) along with all other project disciplines during the very early stages of the design process. This way all stake holders are involved in a holistic, integrated design that optimizes the project energy savings along with minimizing life-cycle maintenance cost.

- Insure that heating and cooling load is accurate considering internal load, weather conditions, shell (building) load, and fresh air load. Make sure equipment, especially pumps, are not oversized. Pumps are always oversized in design.

- Avoid the use of dry fluid coolers if possible. They will reduce installation cost but they do add another component that can break. The simpler the design the better. Ensure proper material is used. PVC is not good on the condenser water circuit!!!!!

- $\quad$ OBTAIN VERIFIED \& ACCURATE HEATING AND COOLING AND ANNUAL PROFILES BEFORE DESIGNING EARTH COUPLING

\section{Other suggestions and comments to this survey}

- For local contracts (JOC, BOA, etc.), OMA/SRM funds can only be used for construction; not for engineering studies. GSHP systems require a 24 HR heat transfer test for proper sizing of well fields. The engineering requirement is similar to soils testing for new construction. The only option which a garrison has is an SCR (Services Request) for contracting an A/E firm for this specialized work.

- WE would like to have a good study completed on a validation of GHP resources available for Fort Irwin.

- We've had problems with undersized loops and/or ground temperature drift causing capacity issues-particularly with cooling. Also had a few cases of greatly increased maintenance costs compared with traditional systems.

- Much of the specific data I provided were estimations at best, based on energy audits I have done at several Army installations. The real specifics must come from the Energy Managers and Engineers at each particular installation. We are a national center serving many Army installations. By installation I mean an entire Army base or post consisting of hundreds (sometimes thousands) of buildings. In the Army often times one bad install of a GHP system will leave a bad taste in everyone's mouth and prevent future installs at that particular installation, even though the technology is very good. Most often times Army installations have under staffed maintenance personnel with very little experience. I have performed energy audits at installations where the designer, the installer, or the manufacturer did not do all due diligence and the project turned out bad. On these installations it is very difficult to get traction for GHP systems. If the Army is going to be successful on installing GHP systems on a large scale it must get some good TCT testing, design, and construction of these systems from cradle to grave along with proper training of the maintenance staff where required. I suggest keeping the systems simple and make them easy to maintain. On large scale systems I say sticking with the onepipe concept is a good way to go. On smaller scale systems this is not always necessary. I personally would like to see some demonstration projects where identical buildings with similar usage patterns can receive GHP systems and their energy performance and maintenance issues be compared to more traditional systems (air-cooled chillers, boilers, central station AHUs with VAV boxes with reheat). We are trying to do this at Fort Banning, GA in the Starship Barracks area of the installation. There are 8 each almost identical building at 284,000 sf each. The GHP industry needs to really get on board with Dedicated Outside Air System (DOAS) industry if these things are going to have wide 
scale application beyond the residential level on military installations. Even at the IGSHPA conference this year I saw no speakers on how DOASs can aid in the large scale application of geoexchange systems. The only manufacturer I know that makes a water source DOAU is ClimateMaster. With ASHRAE 62.1 and 189.1 requirements we must take a holistic systems approach to the entire building from cradle to grave. If we ignore the ventilation side of the equation we could be unsuccessful. The Army's big push is in saving energy and measuring that energy savings thru metered data. This data is currently lacking on completed GHP systems. Complete energy consumption of the entire building must be analyzed and sub-metered to compare apples to apples. One thing I have noticed on energy audits is if the HVAC system or controls are too complicated then the maintenance staff will disconnect or override the controls so they understand the system. Therefore if it can stay simple it will be better, while still being modern enough to optimize energy savings. The Army Construction Engineering Research Laboratory (CERL) is really pushing combined heat and power plants and has not really emphasized GHP technology in my experience with them. They have a big influence on many in Army leadership and this could represent a hindrance to large scale installs of GHP systems on Army installations. Bottom-line: I believe if the Army could be convinced that from a holistic system and life-cycle cost approach that these systems could pay for themselves they could support this technology on a bigger scale. Additionally we need to get more creative in utilizing removed heat from barracks for example to heat domestic hot water, or use at an adjacent dining facility or data center. The Army has building clusters that can take big advantage of bulk load diversity and usage patterns to optimize geo-exchange systems.

- Poor initial design will result in a poor quality end product. Over-sizing systems will cause extra maintenance issues and unhappy building occupants. Make sure your system is designed to accurate building loads.

- GHP's if not designed and installed correctly will produce lots of problems at the facility, including mold, leaks, in-adequate maintenance, etc.

- Cost benefits can be difficult with LCCA. Different professionals rate differing factors on the LCCA

- NEED PRIVATE SECTOR PPA PROGRAMS...DO NOT USE USACE AND EXPECT COST CONTOLS OR SEASONED DESIGN EXPERTISE

- Train designers, installers and commissioning people of WHOLE PROJECT design and technical management from concept to commissioning and, where appropriate, through the first year's operation.

- This is a great technology that gets a bad reputation when systems are improperly designed and maintained.

- Under-designing of heating and cooling loads are too common, with resultant under designed earth coupling, resultant under-signed heating and cooling equipment, resulting in use of expensive fossil or electric augmentation, resulting in poor monitored efficiencies. 
APPENDIX B: COMMENTS FROM RESPONDENTS WITH REGARD TO THE SURVEY OF MINIMUM QUALIFICATIONS OF GHP DISCIPLINES 


\section{APPENDIX B: Comments From Respondents with Regard to the Survey of Minimum Qualifications of GHP Disciplines}

\begin{tabular}{|c|}
\hline \\
\hline $\begin{array}{l}\text { every category save well driller and professional degrees. I would object vehemently to mandated } \\
\text { participation in ACCA, IGSHPA, NGWA etc. All cost money to belong. If this project intends to mandate } \\
\text { participation elsewhere, then why do I need this certification. ... I'll just get the other guy's. Education } \\
\text { requirements outside of those required for professional degrees are elitist in my opinion. Virtually every task } \\
\text { in a geo installation (outside of design) is skilled labor easily performed by any high school dropout. Well } \\
\text { drilling standards that include injection and standing column wells that are illegal in some states does not } \\
\text { enhance public confidence. Quite the contrary if national geo certification endorses illegal practices it may } \\
\text { do the opposite in those states. Better to identify type of system and yield to local DEQ. }\end{array}$ \\
\hline \\
\hline \\
\hline $\begin{array}{l}\text { ld have at least five years of experience } \\
\text { mp and from any of the manufacturers of } \\
\text { mpsociation, i.e., ACCA etc. }\end{array}$ \\
\hline $\begin{array}{l}\text { THE } \\
\text { OR H }\end{array}$ \\
\hline $\begin{array}{l}\text { d for a geo knowledge ACROSS the spectrum from design to } \\
\text { o SIMPLY monitor (not a high price BMS package) the first }\end{array}$ \\
\hline \\
\hline $\begin{array}{l}\text { Years of college, unless an engineering discipline, have nothing to do with geothermal design. Education for } \\
\text { Geothermal, with some prerequisites in math, might be more appropriate. I agree with some form of OJT } \\
\text { requirements for new people entering the field. Having a test, or documented designs and installations, that } \\
\text { can be reviewed are a much better indicator for verifying existing professionals in the field. Does it matter } \\
\text { that someone has a college degree if they don't know what thermal conductivity/diffusion is? I find that a lot } \\
\text { of this is more about setting the bar too high with a checklist of credentials that don't really indicate } \\
\text { experience/knowledge pertinent to creating designs/installations that work. Smells more of creating "barriers } \\
\text { to entry" to folks that can move this industry forward with out of the box ideas, that bring the cost down and } \\
\text { make systems more economical to install. I think you can have both quality and reasonable cost without a } \\
\text { lot of red tape. Let's focus more on the specifics required to get a working design and less on "barriers to } \\
\text { people entering this field." If you want a college degree, be specific about which ones. If you want } \\
\text { certifications, be specific about why each one is required and possible alternate ways of meeting the same } \\
\text { requirements. I have a lot more to share on this topic. }\end{array}$ \\
\hline $\begin{array}{l}\text { You have not included NGWA Certified Vertical Closed Loop Driller designation in your list of options. } \\
\text { NGWA believes that completing a fee-based course and then taking an open-book exam on the course } \\
\text { content WITHOUT also having real world demonstrated competency attested to by a third party is NOT an } \\
\text { adequate qualification to open the subsurface and groundwater to the risk of contamination. }\end{array}$ \\
\hline VAC field Many are dvslexic and mav have \\
\hline
\end{tabular}




\section{Comments}

Distinguish between less expensive horizontal loops and vertical bores. Grout crew and heat fusion crew are separate. Trainers need to be a Professional Engineer or equivalent for credibility. There are too many Trainers now, and not enough candidates, so classes often get cancelled. Promote to the young with an apprentice program. Thank you for conducting this.

Ensure adequate applications of national, state, local building, plumbing, electrical codes. Include all necessary Standards. Standardize all systems upon national level Codes with inherent flexibility for local situations. Include full awareness of including any training which may encroach upon a recognized trade certification to avoid conflict.

One of the biggest holes we find in the GSHP industry in Texas is not the advanced training, but the basics. We are renovating residential GSHP installs all the time with inadequate duct work and installation techniques such as accessibility, refrigerant charge, vibration isolation, filtration, etc. Please add the basics to the training criteria for a GSHP designer/installer.

I believe a national license and standard to be a good thing.

IGSHPA Accredited Driller should not be promoted, should not be included in this survey, and should be eliminated from the GHP industry. There is no real value in this accreditation. There is high probability that this accreditation will be used by individuals, who are not competent to construct vertical loop wells, to attempt loop well construction. This accreditation places both the groundwater and the system performance at risk. IGSHPA Accredited Driller requires no experience or training of the individual, has not established, through a formal process, the skills and competencies required of the driller, and does not require that the accredited individual maintain continuing education. Accreditation is acknowledgement that an individual attended a class and passed a test on the material presented in the class. A type of litmus test would be compare the $\%$ of individuals who take the IGSHPA Accredited Driller course are accredited with the $\%$ of individual who take certification/licensing test and pass. IGSHPA Accredited Driller is a disservice to the GHP industry.

We need a governing body that is not in bed with a major manufacturer. Until that happens, forcing people to endure trainings at either IGSHPA or NGWA will defeat the purpose, since both or neither may become the accrediting body. There needs to be an objective federal accreditation unit that can help to grow the industry, if geothermal is going to live up to its potential.

The NCS has a huge potential for advancing the industry but a critical component is missing the industry discussion. In my experience, one the greatest potentials for underperforming systems is lack of support for the engineer or contractor during their first few systems. The level of support for a newbie is all over the map but mostly inadequate to ensure a high probability. Either require the trainer to provide the support or create a peer based mentoring system. 
APPENDIX C: PRE-DEFINED GHP DISCIPLINES 


\section{APPENDIX C: Pre-defined GHP Disciplines}

Architect: design of overall project architectural considerations, including facility siting and use, aesthetics, regulatory compliance, etc.

GHP System Design Engineer: design and specification of the entire GHP system, including both the ground heat exchanger or open-loop well(s), and the balance of the GHP system. May subcontract appropriate tasks, for example:

- $\quad$ site evaluation to a qualified Site Evaluator

- design and specification of ground heat exchange to a qualified Ground Heat Transfer Designer

- design of open-loop supply, return and standing column well(s), including physical location(s), to a qualified Water Well Designer, Return Well Designer, or Standing Column Well Designer.

Site Evaluator: investigation and evaluation of site environmental conditions, including one or more of the following: safety, regulatory due diligence, hydrogeology, water quality, aquifer temperature change, injection well and/or surface water discharge requirements, and potential impacts to other groundwater and/or GHP system users.

Ground Thermal Conductivity/Diffusivity Tester/Analyst-closed loop only: determination and/or verification and analysis of thermal properties of geological formations from short-term field tests of previously installed vertical ground heat exchangers, drilling logs, etc.

Ground Heat Transfer Designer: design of one or more types of ground heat transfer, including

- closed-loop only: ground-coupled heat exchangers (vertical borehole, horizontal excavation or directional drilling)

- closed-loop only: surface water heat exchangers

- open-loop only: ground water well and/or standing column well heat transfer

Vertical Borehole Driller-closed loop only: construction of borehole(s) for vertical ground-coupled heat exchangers.

Horizontal Directional Driller-closed loop only: construction of directional drilling for groundcoupled heat exchangers.

Trencher/Excavator: construction of GHP system trenching and/or excavation.

Loop Installer/Grouter - closed loop only: installation of one or more types of heat exchangers, including ground-coupled heat exchangers (vertical or horizontal), surface water heat exchangers, etc., as well as system integrity testing, flushing and purging, flow and balance testing.

Water Well Designer-open loop only: design of production well(s) and well field operation, including well location(s), water quality and flow requirements for the GHP system. 
Return (Recharge) Well Designer-open loop only: design of return (recharge) well(s) and the return well operation, including evaluation of the potential for the precipitation of dissolved minerals and the deterioration of the recharge capacity over time.

Standing Column Well Designer-open loop only: design of standing column well(s) and well fields, including water quality and flow requirements for the GHP system, and the potential use of bleed water to enhance performance.

Water Well Driller - open loop only: construction, development, completion, and protection of physical water supply well, return well and/or standing column well.

Water Well Pump Installer-open loop only: sizing, installation, service, and repair of water well pumping systems and related GHP equipment.

Pipe/Tubing Technician: construction of approved pipe and connections (joints/headers/manifolds, etc.) to designated termination point (building wall, mechanical room, or flow center, etc.).

- HDPE pipe fusion technician - construction of HDPE pipe fusion connections

- PEX pipe joint technician - construction of PEX pipe connections

- Copper pipe technician- construction of copper pipe connections (DX systems)

- Other pipe/tubing technologies

Mechanical System Installer: installation of interior GHP system, including heat pump equipment, pump system, forced air and/or water distribution systems, and associated control systems.

GHP System Commissioning Agent: verification of GHP system installation, functionality, and capability of being operated and maintained to perform in conformity with applicable regulations and contract specifications, in addition to the system design intent.

GHP System Operation and Maintenance Personnel: troubleshooting of GHP system problems, repair or replacement of malfunctioned components, accomplishment of routine maintenance to keep GHP systems operating within design specifications.

GHP System Regulator: adoption and enforcement of regulations governing design, installation, operation and maintenance of GHP systems.

GHP System Trainer: delivery of training programs covering design, installation, operation and maintenance of GHP systems. 